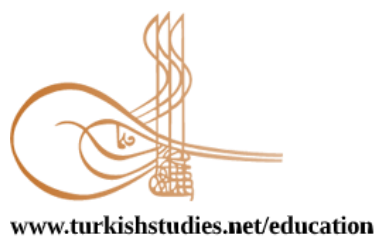

www.turkishstudies.net/education
Turkish Studies - Educational Sciences

eISSN: 2667-5609

Research Article / Araștırma Makalesi

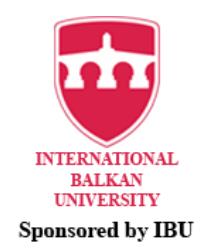

Sponsored by IBU

\title{
Eğitim Sosyolojisinin Türkiye'deki Gelişimi Üzerine Bir Değerlendirme
}

\author{
An Analysis on the Development of the Sociology of Education in Turkey
}

\author{
Cengiz Aslan*
}

\begin{abstract}
One of the discussions in the literature is that sociology of education is a sub-discipline of educational sciences, as well as a discipline that deals with and examines the issues and problems related to "education" with the methods and approaches of sociology. In this context, it can be said that the definition and limits of sociology of education have become controversial and ambiguous. The present study examined the development of sociology of education at higher education level in Turkey. It is aimed with this study to introduce the development of sociology of education at higher education level in Turkey, from the beginnings of Meşrutiyet until today, by investigating faculties, institutes, journals and courses which have important roles in the institutional developments of both the sociology and educational sciences. It is a historical research. The data was analyzed according to the descriptive analysis approach. As a result of the study, it is realized that although sociologist claim that sociology of education is a sub-discipline of sociology, the field historically placed and developed in the field of educational sciences in Turkey. It is found that there isn't supporting documents that the academic structuring of the Sociology Departments includes sociology of education related studies in wellknown universities in Turkey. Both in Istanbul University Faculty of Literature, Faculty of Law and Faculty of Economics and in Ankara University Faculty of Languages, History and Geography (DTCF), and their academic structuring in sociology departments, institutes, publications, courses there aren't "sociology of education". In Turkey, academic improvement of the sociology of education continued within educational sciences since 1965, with foundation of Faculty of Educational Sciences in Ankara University. Although sociology of education, as an interdisciplinary field of study, uses methods, techniques and data from sociology; it is institutionalized more in the field of educational sciences rather than sociology in Turkey.
\end{abstract}

Structured Abstract: One of the discussions in the literature is that sociology of education is a sub-discipline of educational sciences, as well as a discipline that deals with and examines the issues and problems related to "education" with the methods and approaches of sociology. In this context, it can be said that the definition and limits of sociology of education have become controversial and ambiguous.

Although the previous sociologists interested in educational issues, the relationship between sociology and educational sciences dated in later periods. In Turkey, sociology of education founded as a discipline in the middle of 20th century. On the other hand, foundation and development of sociology of education couldn't be separated from development and institutionalization of educational sciences in Turkey.

The present study examined the development of sociology of education at higher education in Turkey. Main faculties, institutes, journals and courses which have important roles in the institutional developments of

\footnotetext{
* Dr. Cengiz Aslan, Ankara Üniversitesi, Eğitim Bilimleri Fakültesi, Eğitim Bilimleri Bölümü. Dr., Ankara University, Faculty of Educational Sciences, Department of Educational Sciences. ORCID 0000-0003-3710-9838 
both the sociology and educational sciences were investigated from the beginnings of Meşrutiyet to today. It is a historical research. Historical researches conduct data systematically and analyze them in an attempt to understand the facts and events in a certain period of history (Fraenkel vd., 2012:535-537). The data was analyzed according to the descriptive analysis approach.

As a result of the study, it is found that there isn't supporting documents that the academic structuring of the Sociology Departments includes sociology of education related studies in well-known universities in Turkey. Both in Istanbul University Faculty of Literature, Faculty of Law and Faculty of Economics and in Ankara University Faculty of Languages, History and Geography (DTCF), and their academic structuring in sociology departments, institutes, publications, courses there aren't "sociology of education". Additionally, in sociology undergraduate programs although there are various courses related to sub-disciplines of sociology, such as family sociology, religious sociology etc., there aren't any courses related to sociology of education. This indicated that as for sociologists in the field of sociology, "sociology of education" is a field that is not interested too much.

In the Turkish famous sociology journal (İçtimaiyat Mecmuas1/İstanbul University Journal of Sociology) published between 1917 to 2020 there are very limited number of publications related to "sociology of education". In İstanbul University Journal of Sociology "education" related articles are very limited and this demonstrate that it is not an interested issue for most sociologist. The limited interest to education in those wellknown journals, which are very important publications to institutionalization of sociology in Turkey, shows that "sociology of education" is not the agenda of the field of sociology in Turkey. In Turkey, although sociologist claim that sociology of education is a sub-discipline of sociology, historically the field placed and developed within the field of educational sciences. In other words, sociology of education as a practical and interdisciplinary field, has grown and developed in the field of educational sciences.

In 1965, when Ankara University Faculty of Educational Sciences was founded, the sociology of education department placed as a separate chair in the faculty structure. In 1974 departments were restructured and it's name changed as Social and Historical Foundations of Education. Between 1982 to 1997 sociology of education placed within the department of Curriculum and Instruction in Social and Historical Foundations of Education division. From 1997 to 2007 it is placed within the Department of Educational Sciences, division of Social and Historical Foundations of Education. Sociology of education studies carried out within the Department of Cultural Foundations of Education in division of Social and Historical Foundations of Education between 2007 and 2016. Today it is carried out its studies in division of Social and Historical Foundations of Education. The first graduate program in the sociology of education started in Ankara University in 1967. Later it was founded in Gazi University in 1998 and Samsun On Dokuz Mayıs University in 2009. Result of this study showed that although it uses methods, techniques and data from sociology; sociology of education is institutionalized more in the field of educational sciences rather than sociology in Turkey.

Keywords: Sociology, educational sciences, sociology of education, educational sociology, university.

Öz: Alanyazındaki tartışmalardan biri eğitim sosyolojisinin, sosyolojinin yöntem ve yaklaşımlarıyla "eğitim" ile ilgili konu ve sorunları ele alıp inceleyen bir disiplin olduğunun yanı sıra eğitim bilimlerinin bir alt disiplini olduğudur. Bu çerçevede eğitim sosyolojisinin tanımı ve sınırlarının, tartışmalı ve muğlak olduğu söylenebilir. Bu çalışmada, Türkiye'de eğitim sosyolojisinin yükseköğretimdeki gelişimi irdelenmiştir. Araştırmanın amacı, Meşrutiyet döneminden günümüze eğitim sosyolojisinin, hem sosyoloji hem de eğitim bilimlerinin kurumsal gelişiminde önemli yeri olan fakülte, enstitü, dergi ve dersler üzerinden, Türkiye'de yükseköğretim kademesindeki gelişimini ortaya koymaktır. Araştırma tarihsel araştırma türünde olup verileri betimsel analiz yaklaşımına göre analiz edilmiştir. Araştırma sonuçlarına göre, Türkiye'de eğitim sosyolojisi disiplininin, her ne kadar sosyolojinin bir alt disiplini olduğu kabulü sosyologlar arasında oldukça yaygın olsa da, aslında tamamıyla varlık alanı, ortaya çıkması ve gelişmesi eğitim bilimlerinin içerisinde olmuştur. Türkiye'de başlangıcından günümüze İstanbul Üniversitesi Edebiyat, Hukuk ve İktisat Fakültelerinde, Ankara Üniversitesi Dil ve Tarih-Coğrafya Fakültesi'nde ve diğer üniversitelerdeki Sosyoloji Kürsüleri/Bölümlerinin akademik örgütlenmesinde, enstitülerinde, araştırmalarında, yayınlarında ve derslerinde eğitim sosyolojisinin varlığına ve gelişimine ilişkin kanıtlar ileri sürmek zordur. Ankara Üniversitesi Eğitim Bilimleri Fakültesi’nin kurulmasıyla, 1965 yılından itibaren eğitim sosyolojisi disiplininin akademik gelişimini, eğitim bilimleri içerisinde sürdürdüğü söylenebilir. Türkiye'de eğitim sosyolojisinin, sosyoloji disiplininden ziyade eğitim bilimleri içerisinde 
kurumsallaştığı ve geliştiği görülmüştür. Elbette bu sonucun, eğitim sosyolojisinin sosyolojiden etkilenmediği/etkilenmeyeceği anlamına gelmediği, Türkiye'deki seyrinde eğitim bilimleri içerisinde kurumsallaşarak farklı disiplinlerin verilerini kullanan disiplinlerarası bir disiplin olduğu anlamına geldiği de söylenmelidir.

Anahtar Kelimeler: Sosyoloji, eğitimbilimleri, eğitim sosyolojisi, eğitsel sosyoloji, üniversite.

\section{Giriş}

Eğitim sosyolojisinin, "eğitim" ile ilgili konu ve sorunları sosyolojinin yöntem ve yaklaşımlarıyla ele alıp inceleyen bir disiplin olduğu kabulüyle birlikte eğitim bilimlerinin bir alt disiplini olduğu alanyazındaki tartışmalardan biridir. Bu çerçevede eğitim sosyolojisinin tanımı ve içeriği, sosyolojinin veya eğitim bilimlerinin konu ve yöntemlerinin işe koşulmasına bağlı olarak farklılaşmaktadır. Akyüz (1992:75), eğitim sosyolojisindeki bu farklılaşmanın, malzeme olarak kullanılan kaynakların birbirinden farklı olması, farklı kavram, unsur ve metodların kullanılmasının sonucu olduğunu belirtmektedir. Diğer bir ifadeyle bilim alanlarının sınırlarının esnekliği, geçirgenliği, iç içeliği, eğitimin merkezinin veya çevresinin ne olduğunu belirlemekte, muğlaklık ve müphemlik görüntüsü ortaya çıkarmaktadır. Bu durum eğitim sosyolojisinin deneyimlediği bir tarihsel süreksizliğe değil, sürekliliğe karşılık gelmektedir. Yine de eğitim sosyolojisinin belirsizliğinin sürekliliğinin, günümüze yaklaştıkça süreksizliğe dönüşebilmesi, tarihsel sürekliliğinin ortaya konulmasıyla daha iyi anlaşılacaktır. Bu süreçte eğitim sosyolojisinin buluştuğu toplumbiliminde alt uzmanlık alanlarının ortaya çıkması Tan (1981:27)'a göre toplumsal gerçekliğin, bütünün ve bütünün parçalarıyla karşılıklı ilişkisinin sürekli göz önünde tutulması zorunluluğuyla bir parçalanma görünümü almasını engellemektedir. Tolan (2005:136), benzer biçimde sosyolojinin temel kurumsal, kavramsal ve metodolojik bilgilerinin özümsenmiş olması koşuluyla özel sosyolojilerin ortaya çıkabileceğini savunmaktadır. Cangızbay (1999:7) ise sosyolojilerin değil sosyolojinin olması gereğini vurgulayarak bütüncül bir anlayışı benimsemektedir. Eğribel ve Özcan (2010:14) da benzer biçimde sosyolojinin alt disiplinlere bölünmesini, kendi içinde uzmanlaşmaların (kent, kır, sanat, kültür, iletişim, etnik, yoksulluk sosyolojileri gibi çeşitli alt birimler) ve alan araştırmalarının öne çıkmasını, Türk sosyoloji geleneğine ve mirasına karşıt bir eğilim olarak görmekte, Batı'da temel toplum sorunlarının çözüldüğ̈̈ inancıyla toplumun temel sorunlarından bağımsız uzmanca bir iş olarak tanıtılması eleştirisinde bulunmaktadır. Bu tür değerlendirmeler, Türkiye'de sosyolojinin kendi içinde alt disiplinler olarak uzmanlaşılmasına yönelik farklı yaklaşımlara sahip olunduğunun göstergesi olarak kabul edilebilir.

Sosyoloji biliminin öncülerinin eğitimle ilgili konuları ele almalarına karşın, "sosyoloji” ile "eğitimbilim" arasındaki köprü çok daha sonra kurulmaya çalışılmıştır (Topçuoğlu, 1971:3-5). Bununla birlikte, Ismayıl Hakkı (1339:3)'ya göre terbiyenin “İctimâ'iyyât nokta-i nazarından tedkîk edilmesi" gerektiğini sistematik bir tarzda ilk defa konu edinen ictimâ'iyyâtçı Durkheim'dır. ${ }^{1}$ Durkheim'a gelinceye kadar Terbiye Fenni demek olan Pedagocya, bazı istisnalar bir kenara bırakılırsa "ruhiyyâta istinâd ediyor", kuvvetini hep bu ilmin malumlarından almağa çabalıyordu. Durkheim'ın fikri ise eğitim, din, ahlâk, hukuk ve iktisâd gibi “ictimâ'î bir müessesedir ve ictimâ'î müesseseler gibi tedkîk edilmesi” yönündedir. Terbiyenin ictimâ'iyyâtı demek olan bu yeni ilim, terbiye ilmidir. ${ }^{2}$ Dolayısıyla eğitimin de diğer toplumsal kurumların incelenmesi gibi başlı başına bir bilim alanı olduğu ve incelenebileceği anlayıșı bulunmaktadır.

\footnotetext{
${ }^{1}$ İçtimaiyat dergisinin 5. sayısında Durkheim'in “İlmi-i Terbiye ve İçtimaiyat” adlı yazısı yayınlanır. Bu yazı, Sadrettin Celal (Antel) tarafından Osmanlı Türkçesine aktarılır.

2 19. yüzyılın başında "Terbiye Fenni”" olarak tanımlanan Pedagoji, Baltacıoğlu’na göre "Fransızların: "Pédagogie sociale" tabiri, Almanların: "Sozial padagogık" tabiri, Amerikalıların: "Educational Sociology" tabiri terbiyenin ictimâ'iyyât noktai nazarından tedkîki temayülünü göstermekle beraber ictimâ'î melekelerin terbiyesine müteveccih bir nazariyeyi işaret etmektedir. Terbiyenin ictimâ'iyyâtı demek olan bu yeni ilim, terbiye ilmidir. Terbiyevî hadiseleri tedkîk eden bu ilme de Terbiyevî İctimâ'iyyât: Sociologie de l'éducation yahut Terbiyeler İlmi diyebiliriz. Bu ilmin mevzu'1 mâzi ve haldir.
} 
Durkheim'ın çalışmalarının ardından önceleri "eğitsel sosyoloji” (educational sociology) ve daha sonraları "eğitim sosyolojisi" (sociology of education) başlıkları altında çok sayıda çalışma üretilmiştir. Swift (2017:3)'e göre Durkheim' dan bugüne eğitim sosyolojisi (sociology of education), insanın sosyal doğasını anlamamızı ortaya çıkaracak sosyo-psikolojik teori ve araştırma anlayışıyla gelişmiştir. İlk başlarda üniversitelerin eğitim bölümlerinde "educational sociology" olarak adlandırma eğilimi varken günümüze yaklaştıkça "sociology of education" kavramını kullanma tercihi artmaktadır (Morrish,1972:36). Buna karşın Taylor (1967), "educational sociology" ve "sociology of education" kavramlarının eğitimsel veya sosyal problemlere vurgu ile sosyolojik problemlere vurgu arasındaki farkı korumayı sürdürebilmek için ayrı kullanılmasını teklif eder (Swift, 2017:4; Morrish, 1972:36). Bu her iki anlayıştan daha geniş bir alanı olan eğitimin sosyal temelleri ise, genellikle eğitim tarihi, eğitim felsefesi, eğitim sosyolojisi (sociology of education) ve karşılaştırmalı eğitimi içermektedir (Stalcup, 1968:5). Görüldüğü üzere, alanyazında her iki kavramın neye karşılık geldiğine ilişkin bir uzlaşmanın olmadığı söylenebilir. Bununla birlikte Türkiye'de eğitim sosyolojisi olarak adlandırılan bilim dalı, literatürdeki ikili yaklaşımın ikisini birden ifade etmektedir: Eğitim sosyolojisi (sociology of educatıon) ve eğitsel sosyoloji (educatıonal sociology). Baltacıoğlu (1340:3) “educational sociology” kavramının eğitimin Durkheim'ın ictimâ'î müesseseler gibi incelenmesi gerektiği anlayışına karşıllı gelmediğini belirterek, bunu karşılayan kelime olarak "terbiyevî ictimâ'iyyât: Sociologie de l'éducation" kavramını kullanmaktadır." Topçuoğlu (1971:2-5) ise eğitim sosyolojisinin, eğitim kurumlarını ve eğitim örgütlerini inceleyen sosyolojinin bir dalı olduğunu belirtmektedir. Ancak daha sonraları bu iki akımın ortak bir çizgi üzerinde birleşme çabaları görülmektedir (Ergün,1994:10). Bu çerçevede "sociology of education" ve "educational sociology" kavramlarının tanımının, tarihsel süreç içerisinde dönüşümüyle beraber birbirinden farklılık gösterdiği söylenebilir. Diğer bir ifadeyle Türkiye'de bu ikili yaklaşımın sonucu olarak eğitim sosyolojisi, makro boyutta eğitim sistemlerini, eğitim olayları, kültürel ve toplumsal olayların eğitimsel neden ve sonuçlarını; mikro boyutta ise, okulu, okulun iç ve dış toplumsal etkileşim biçimini, sınıfı ve okulun varlık nedeni olan eğitim ve öğretim olaylarını (sistem, program, öğretmen, öğrenci, yönetici ve veli ögelerini), toplumsal edimlerini ve açılımlarını incelemektedir (Doğan, 2018:11).

Görüldüğ̈u üzere eğitim sosyolojisinin tanımı ve sınırlarının her dönemde tartışmalı, girift ve gri bir hal aldığı söylenebilir. Kuşkusuz bu halin eğitim sosyolojisinin özellikle eğitimbilimleri, sosyoloji, psikoloji, felsefe, ekonomi biliminin verilerini kullanan disiplinlerarası bir disiplin olmasından kaynaklandığı söylenebilir. Sözer ve Sever (2012:70)'e göre, post-modern yaklaşımların disiplinlerarası duvarları adeta bir virüs gibi yiyip bitirmesi, neyin eğitim sosyolojisi neyin felsefe ya da neyin siyaset bilimi olduğunu ayırma imkanını neredeyse tamamen ortadan kaldırmıştır. $\mathrm{Bu}$ belirsizliğe karşın eğitim sosyolojisi sosyolojiden, pedagojiden ve mukayeseli eğitimden ayrı olarak gerekliliğini kabul ettirmeye çalışan, normatif, empirik ve pratik yaklaşımlar arasında yerini ve yöntemini keşfetme süreci yaşamaktadır (Bilhan, 1996:14). Bu süreçte eğitim sosyoloji, antropoloji ve psikoloji gibi bilimlerin kendilerine mahsus ve kendilerince daha önemli konuları olduğu için bu bilimlerin temel objesi olamamıştır (Akyüz, 1992:49). Buna karşın eğitim sosyolojisi disiplininin, günümüz araştırmacılarının neredeyse tamamında da yer bulan "sosyolojik yöntemin toplumsal bir olay olan eğitime uygulanmasıyla ortaya çıktı̆̆ı" (Doğan, 2018:10; Tezcan, 1985:3) değerlendirmesi, Durkheim'c1 anlayışın karşılığı olarak nitelendirilebilir.

Türkiye'nin ilk sosyologlarının / düşünürlerinin gündemi "bu memleket nasıl kurtulur?" sorusunda karşılı̆̆ını bulmuştur. Ülken (2008:7), dönemin sosyologlarının (Gökalp, Prens Sabahaddin, Mehmet Ali Şevki ve daha birçokları) ilim için ilmi bir yana bırakıp, siyaset için, içtimai reform için ilim yapmak zorunda kaldıkları ve bu yüzden politika ve sslahatın beklediği acele

Terbiye İlmi doğrudan doğruya olmuş veya olmakta olan terbiyeyi tedkîk eder. Bk. Ismayıl Hakkı, Ictimâ’iyyât Nokta-i Nazarından Terbiye, İstanbul, Matbaa-1 Amire, 1340, s.3-32.

${ }^{3}$ Ingilizce metinlerde ise Durkheim'in eğitime sosyolojik bakışı her iki kavram ile karşılanmaktadır. 
yüzünden tetkiklerini yarıda bıraktıkları değerlendirmesinde bulunmaktadır. Türkiye'de sosyolojiye ilk ilgi duyanlar arasında sosyolojinin nesnesinin "toplum" değil fakat "polity" (politik toplum) olduğunun sayıltılanması (Çelebi, 2010:56) da bu çerçevede düşünülebilir. Bu değerlendirmelerin aslında iktidar ve bilim ilişkisi ele alındığında diğer tüm bilim alanları içinde geçerli olabileceği, dönemin terminolojisi içerisinde yer alan terbiye ve pedagojinin de böylesi bir kaygı içerisinde eğitim yoluyla toplumsal sorunları çözme derdiyle meşgul olduğu söylenebilir. Bunun yanı sıra Kaçmazoğlu (2010:218)'nun dış gelişmelerin yönlendirdiği Türk sosyolojisinin, önce Fransız ve İngiliz sonra Alman ve daha sonra da Amerikan sosyolojisinin etkisinde kaldığı değerlendirmesi, kuşkusuz genelde bilimlerin özelde de eğitim bilimlerinin gelişiminin özeti niteliğindedir. Diğer bir ifadeyle, bilginin vulgarizasyonunda bilgi merkezlerinin etkisinin çevreye yayılmasının sonucu, bu etkilerin / etkileşimlerin kaçınılmaz olduğu söylenebilir.

Türkiye'de 20. yüzyılın ilk çeyreğinde sosyolojinin "henüz yeni teşekkül etmiş ve felsefi devrinden yeni çıkmış bir ilim olduğu" ve hatta bazı mütefekkirlerin "böyle bir ilmin mevcudiyetini bile inkar ettiği" (Necmeddin Sadak, 1917:15) değerlendirmesinde bulunulduğu düşünüldüğünde, eğitimbilimlerinin ve alt disiplinlerinin de aynı akıbeti deneyimlediği söylenebilir. $\mathrm{Bu}$ inkarın yansımaları dönemin dergilerinde de görülür. İçtimaiyat dergisinin ilk iki sayısında (1917) Necmettin Sadak'ın "İçtimaiyat Nedir?" ve "İçtimaiyat bir ilim midir? başlıklı yazıları ile Darülfünun Edebiyat Fakültesi Mecmuasında Baltacıoğlu'nun "Terbiyenin ilim gibi tetkikine medhal" (1916), "İçtimaiyat nokta-i nazarından terbiye" (1924) yazıları, bu iki yeni bilim alanının birbirinden ayrı olarak ele alındıklarını ve bilim alanı olarak ele alınması gerektiğini gösteren yazılardır. Ülken (1941:14-17), sosyolojinin cemiyeti dört zümrede (umumi, morfolojik, rabitalar, normatif sosyoloji) incelediğini; toplumsal ilişkileri inceleyen umumi sosyolojinin, temel ve müştak (türemiş, yeniden oluşturulmuş) hadiseler olarak iki gruba ayrıldığını ve başlıca ekonomik-politik, hukuki, ahlaki, bedii (sanat), fikri (filoloji ve filozofi) ve dini (din ve sihir) içtimaiyat kısımları olduğunu belirtmektedir. Bu sınıflandırmaya karşın Kanad (1958:VI) terbiye sosyolojisini, umumi sosyoloji ile uğraşan bazı sosyologların araştırmalarını, çocukların terbiyesine tesir eden çeşitli sosyal faktörler üzerine topladıkları ilim dalı olarak görmektedir. Bu çerçevede Türkiye'de eğitim sosyolojisinin sosyoloji içerisinde geliştiği değerlendirmeleri de günümüz araştırmacılarında (Tezcan, 1985:3; Doğan, 2018:71; İnal, 2014:11; Esgin, 2013:149) oldukça geniş bir yer tutmaktadır.

$\mathrm{Bu}$ araştırmanın amacı, sosyoloji ve eğitim bilimlerinin kurumsal gelişiminde önemli yeri olan fakülte, enstitü, dergi ve dersleri üzerinden eğitim sosyolojisinin, Meşrutiyet döneminden günümüze Türkiye'de yükseköğretim kademesindeki gelişimini ortaya koymaktır. Araştırmada, Türkiye'de eğitim sosyolojisi disiplininin hangi bilim alanı içerisinde yer aldığı ve geliştiği tartışılmaktadır. Araştırma, tarihsel araştırma türünde olup verileri betimsel analiz yaklaşımına göre analiz edilmiştir.

\section{Meşrutiyetten İstanbul Üniversitesi’ne Eğitim Bilimleri ve Sosyoloji}

\section{Fakülteler/Kürsüler/Dersler}

Türkiye'de eğitim sosyolojisi disiplininin ortaya çıkması ve gelişimi, eğitim bilimlerinin yükseköğretim kademesinin kurumsallaşma sürecinden bağımsız olarak değerlendirilemez. $\mathrm{Bu}$ çerçevede yükseköğretim kademesindeki akademik yapılanmanın, genelde eğitim bilimlerinin, özelde bir bilim alanı olarak eğitim sosyolojisinin gelişiminde önemli bir yeri bulunmaktadır. Eğitim bilimlerinin alt disiplinlerinin, dönemin terminolojisi içerisindeki karşılıklarından biri olan usûl-i terbiye ve tedris" dersi ${ }^{4}, 1900$ yılında Darülfünun'da Edebiyat Fakültesi’ndeki derslerden biridir.

\footnotetext{
${ }^{4}$ Eğitim bilimleri alt disiplinlerinin, Meşrutiyet dönemi terminolojisi içerisindeki karşılığı olarak pedagoji, fenn-i terbiye, terbiye, ilm-i terbiye, terbiye-i etfal, tedris usulü gibi dersler; Cumhuriyet'in yaklaşık olarak ilk çeyrek döneminde çocuk ve gençlik psikolojisi, tecrübi psikoloji, eğitimsel psikoloji, eğitimsel sosyoloji, karşılaştırmalı eğitim, özel eğitim, genel eğitim tarihi, Türk eğitim tarihi, istatistik ve fizyoloji, ruhiyat, köycülük ve halkçılık gibi disiplinler aracıllı̆̆yla ele alındığı görülmektedir. Bu konuda bk. Refia Uğurel-Şemin, Eğitim Bilimlerinin Üniversiteye Girişi: Pedagoji Enstitüsü’nün
} 
1912 tarihli Darülfünun Nizamnamesi taslağına göre Darülfünun, Ulum-i Şer’iye, Ulum-i Hukukiye, Ulum-i Tıbbiye, Ulum- i Edebiye ve Fünun biçiminde beş şubeden oluşmaktadır. Ulum- i Edebiye şubesi de felsefe, tarih ve coğrafya, ulum-i içtimaiye, edebiyat, lisan takımları / zümreleri olarak beş zümreden oluşmaktadır. Edebiyat şubesinde okutulacak derslerin zümrelere ayrılması sonucunda "terbiye" dersi felsefe zümresinin, "ulum-i içtimaiye" ve "ulum-i iktisad" dersleri ise "ulum-i içtimaiye" zümresinin bünyesindedir. 28 Ağustos 1912 tarihli mazbatada "ulum-i içtimaiye" dersi yer almazken "terbiye" dersi, felsefe dersi ile birlikte ders cetvelinde yer almıştır. Bu taslak, Maarif Nezareti tarafindan üç kez Meclis-i müderrisine (bugünkü fakülte kurulu) tekrar düzenlenmesi için geri gönderilir. Maarif Nazırı Emrullah Efendinin hazırladığı bu düzenleme bütçe yetersizliği, taslağa gelen tepkiler ve hükümetin istifası gibi nedenlerle uygulanamamıştır. Bu düzenleme yerine 26 Mayıs 1913 tarihli İstanbul Darülfünunu'nun Teșkilat-1 İlmiyesi düzenlemesi yürürlüğe girmiștir (Mehmet Ali Ayni, 1927:33-48; Dölen, 2009:313-361). Aslında 1912 tarihli düzenleme uygulanamamış olsa da, 1913 tarihli düzenlemede Edebiyat şubesi ve takımları / zümrelerinde bir farklılık söz konusu değildir. Dolayısıyla Darülfünun'da "ulum-i içtimaiye" dersi 1912'de taslak programda yer alsa da, 1913 tarihinde ders olarak okutulabildiği için sosyolojinin üniversitede yer almasının miladı olarak 1913 tarihi kabul edilebilir. ${ }^{5}$ Ayrıca Baltacıoğlu (1998:220-224) da, 1913'te kendisinin Darülfünun'a terbiye muallimi olarak atanmasından kısa süre sonra, Gökalp'in İlm-i İçtima dersi verdiğini belirtmektedir.

Maarif Nazırlığı 14 Haziran 1331 (1915) tarihinde, Darülfünun şubelerine gönderdiği yazıda Ulum- i Edebiye şubesinin beş zümresi yerine üç bölüme (felsefe, tarih ve coğrafya, edebiyat ve lisan şubeleri) ayrılmasını ve kürsü sistemine geçilmesini istemesine karşın, Edebiyat Fakültesi Kurulu (meclisi muallimin), bunların her birinin ayrı birer şube olmasının yanı sıra Fenn-i Terbiye şubesiyle birlikte altı şubeye ayrılmasını istemiş, ancak bu talep karşılanmamıştır. Bununla birlikte 1917 yılında, Edebiyat Fakültesi Felsefe şubesi komisyonunun aldığı bir kararla "ilmi terbiye ile içtimaiyatın sıkı bağlarla birbirine bağlı bulunduğu, terbiyenin günden güne tecrübi laboratuar tetkikatına yakınlaşmasıyla, ilmi ruhi tecrübi ve ilmi terbiye müesseselerinin karşılaştırmalı tarihi ile meşgul olacak bir ders olarak "terbiyevi içtimaiyat" dersi ile "ilm-i terbiye tarihi" ve "fizyolojik ruhiyat" dersleri programa konulur. Terbiyevi içtimaiyat" dersi Gökalp'in önerisi ve komisyonun aldığı ortak kararla Baltacıoğlu tarafindan verilir (Baltacıoğlu,1998:226-229). 1335 (1919) yılında kabul edilen Darülfünunu Osmani Nizamnamesine göre, Hukuk, Edebiyat, Fünun ve Tip medreselerinden oluşan Darülfünun'da, Edebiyat Fakültesi'ndeki dersler arasında, mantık, ahlak, terbiye, ruhiyat ve ictimaiyyat dersleri bulunmaktadır (Mehmet Ali Ayni,1927:73; Hirsch, 1998:201). Bu çerçevede Türkiye'de eğitim bilimine ilişkin derslerin, Darülfünun'da sosyoloji biliminden önce varolduğu ve ve bu iki alanın birbirinden ayrı alanlar olarak gelişimini sürdürdüğü söylenebilir.

1923 'te Edebiyat Fakültesi'nin dört şubesinden (Felsefe, Tarih, Coğrafya, Edebiyat) Felsefe şubesinin dersleri arasında terbiye, ictimaiyyat, ruhiyat, ahlak, tecrübi ruhiyat bulunmaktadır (Talebe Rehberi, 1339:93-101). 1340 (1924) tarihli İstanbul Darülfünunu Talimatnamesine göre Hukuk, Edebiyat, Fen, İlahiyat ve Tip Fakültelerinden oluşan İstanbul Darülfünunu'nun, Edebiyat Fakültesi'ndeki derslerden bazıları mantık, ahlak, terbiye, ruhiyat, ictimaiyyat, etfaliyat (çocuk bilgisi-psikolojisi) dersleridir (Mehmet Ali Ayni,1927:73; Hirsch, 1998:224). 1930'da Fakültenin Felsefe zümresinin derslerinden bazıları umumi ruhiyat, umumi felsefe, içtimaiyat, terbiye, ahlak terbiyesi ve ahlak dersleridir (Talebe Rehberi, 1930:135-137).

Kuruluşu ve Gelişimi, İstanbul, 1973; Cengiz Aslan, Türkiye'de Eğitim Bilimlerinin Kurumsal Gelişimi. Prof. Dr. Mehmet Ali Kısakürek'e Armağan. Ankara, 2019.

${ }^{5}$ Bu tarih Gökalp'in Darülfünun' da göreve başladığı tarihtir ve kendisine teklif edilen Maarif Nazırlığının yerine Edebiyat Fakültesi'nde İçtimaiyat Müderrisliğini kabul eder. Bk. Hikmet Tanyu, Ziya Gökalp Kronolojisi, Kültür Bakanlığı Yayınları, Ankara, 1981, s. 82. 


\section{Enstitüler}

Sosyolojinin kurumsallaşmasında önemli yeri olan ilk enstitü, İçtimaiyyat Darülmesaisi (Sosyoloji Enstitüsü), Darülfünun Edebiyat Fakültesi’nde $1916^{6}$ yılında, Ziya Gökalp ve arkadaşları tarafindan kurulur (İktisat Fakültesi, 1955:3). Yalvaç (2010:285), 1918 y1lında Gökalp'in üniversiteden ayrılmasıyla bu enstitünün faaliyetlerinin de sona erdiğini belirtmektedir. Daha sonra, 1933 Üniversite reformuyla birlikte İstanbul Üniversitesi'nde 8 enstitü vardır ve bunlardan biri de Milli İktisat ve İçtimaiyat Enstitüsüdür (Hirsch, 1998:316).

Eğitim bilimlerine ilişkin önemli gelişmelerden biri ise, 1915'te Almanya'dan öğretim elemanlarının davet edilmesidir. ${ }^{7}$ Bunlardan biri olan Dr.Anschütz, Edebiyat Fakültesi'ne Pedagoji ve Deneysel Psikoloji (Fenn-i Terbiye ve İlm-i Ruh-i Tecrübi) profesörü olarak atanır. Anschütz tarafından Darülfünun'da Deneysel Psikoloji Laboratuvarı kurulur (Altunya, 2018:49). Diğer bir gelişme ise 1917 yılında Maarif Nezareti tarafından, Fenn-i Terbiye Encümeni oluşturulmasıdır. Bu komisyonun amacı, ulusal eğitimin esaslarının incelenmesi, uygar ülkelerde eğitimbilimle ilgili yayınlanmış önemli eserlerin çevrilmesi ve eğitim bilim öğretmenlerinin gerek haberleşme gerek Fenn-i Terbiye Mecmuasında yayınlanacak makalelerle aydınlatılmasıdır (Baltacığlu, 1998:229). 1920'de ise Darülfunun'da Fenn-i Terbiye (Eğitimbilim) Müzesi’nin kurulmasıdır (Tonguç, 1952:244). 1923'te ise Baltacıŏglu'nun mücadelesini verdiği Terbiye Darülmesaisi kurulur ve 1933 yılına kadar varlığını sürdürür (Altunya, 2018:50). 1923-1924 öğretim y1lı İstanbul Darülfünunu Talebe Rehberine göre, Terbiye Darülmesaisinin görevleri arasında yer alan konulara bakıldığında memlekette eğitime dair bilgilerin toplanıp yazılması, eğitim hakkında toplumsal incelemelerin kolaylaştırılması; okullarda ödül ve ceza usulleri, devam ve devamsızlık olayları, çevrenin eğitimle ilgili olan diğer sorunları (İstanbul Darülfünunu Talebe Rehberi, 1339) gibi konuların aslında eğitim sosyolojisinin gündemindeki konular olduğu söylenebilir. Bu enstitünün sorumlusu Türkiye'nin ilk eğitim sosyoloğu olarak nitelendirilebilecek olan Ismayıl Hakkı Baltacıŏglu'dur.

\section{Dergiler}

Türkiye'de 1908-1911 yıllarında 27 sayı yayımlanan Ulum-1 İktisadiye ve İçtimaiyye Mecmuası ilk sosyoloji dergisi (Çelebi, 2010:53) olarak kabul edilmektedir. 1917'de 1 y1l yayın yapabilen İçtimaiyat Mecmuası ile 1916'dan 1933'e kadar varlığını sürdüren, 1918-1922 yıllarında yayınlarında ara veren ve bu tarihten itibaren tekrar iki ayda bir yayınlanan Darülfünun Edebiyat Fakültesi Mecmuası bu konuda Darülfünun tarafindan basılan dergilerdir. Edebiyat Fakültesi Mecmuasında felsefe, içtimaiyat, tarih, coğrafya ve edebiyat alanlarına ilişkin yazılar yayınlanmaktadır. Bu derginin 49 sayısı çıkmış ve dergide 244 makale ve yazı yayınlanmıştır. (Kazancigil \& Vergili, 2002:35-41). Edebiyat Fakültesi’nin bu dergisinde eğitimbilimlerine ilişkin toplam makale sayısının çeviri metinlerle birlikte 12 olduğu görülmektedir. İçtimaiyat Darülmesaisi'nin yayını olan İçtimaiyat Mecmuası ise, 1917 yılında 6 sayı olarak çıkmıştır (Ercan, 2013:21).

\section{İstanbul Üniversitesi’nden Ankara Üniversitesi’ne Eğitim Bilimleri ve Sosyoloji}

\section{Fakülteler/Kürsüler/Dersler}

6 Haziran 1933 tarih ve 2420 sayılı Resmi Gazetede yayınlanarak yürürlüğe giren "İstanbul Darülfünununun İlgasına ve Maarif Vekâletince Yeni Bir Üniversite Kurulmasına Dair Kanun”una

\footnotetext{
${ }^{6}$ Darülmesainin kuruluş tarihi olarak 1914, 1915 gibi farklı tarihler bulunmaktadır. Bk. Nilgün Çelebi, Türkiye'de Sosyoloji, Türk Sosyologları ve Eserleri II, Genel Eğilimler ve Kurumsallaşma. İstanbul: Kitabevi, s. 54; Mehmet Yalvaç İstanbul Üniversitesi Edebiyat Fakültesi'nde Sosyoloji Eğitiminin Tarihçesi (1912-1982), Türk Sosyologları ve Eserleri II, Genel Eğilimler ve Kurumsallaşma, İstanbul, Kitabevi Yayınları, 2010, s.284.

7 Darülfünun'a yabancı uzman kafilesi 1915 güz döneminde gelir ve birinci grubu oluşturan on bir müderrisin Darülfünun'da görevlendirilmesine ilişkin irâde-i seniyye 31 Ağustos 1331 (13 Eylül 1915)'de çıkar. Bk. Emre Dölen, II. Meşrutiyet Döneminde Darülfünun, Osmanlı Bilimi Araştırmaları, X-1, 2008, s.30.
} 
dayanarak İstanbul Üniversitesi kurulur. Dönemin Milli Eğitim Bakanı Dr. Reşit Galip'in 01.08.1933 tarihinde Hakimiyeti Milliye gazetesine verdiği demece göre, 1933 Üniversite reformuyla ${ }^{8}$ birlikte, daha önce 5 fakülteden oluşan Üniversitede, İlahiyat Fakültesi'nin İslam Tetkikleri Enstitüsü olarak yapılandırılmasıyla, 4 fakülteli (Hukuk, Edebiyat, Fen ve Tıp) bir yapı ortaya çıkmıştır (Hirsch, 1998:316). Bu yeni düzenlemede Edebiyat Fakültesi 11 disiplinden oluşmaktadır ve bunlardan biri de felsefe disiplinidir (Gencer \& Arslan,2004:45). Üniversite reformuyla birlikte, 1933-1934 yılında Hukuk Fakültesi programındaki yeni derslerden biri de sosyolojidir (Erişçi, 1941:164; Fındıkoğlu,1947:17). 1936-1938 öğretim yıllarında Talebe Kılavuzlarına (1936:35; 1937:47) göre, bu fakültedeki felsefe disiplini Umumi Felsefe ve Mantık, Felsefe Tarihi, Ruhiyat ve Terbiye, Sosyoloji ve Ahlâk olarak 4 esas bölüme ayrılmıştır. Gökalp (1956), 1936'dan 1940 yılına kadar sosyoloji dersinin kürsüsüz ve çeşitli güçlüklerle okutulduğunu belirtmektedir (akt.Yalvaç 2010:288). Gerçekten de sosyoloji dersi Hukuk Fakültesi'nde verilmekte, terbiye bölümünde ise Karakter Terbiyesi ile Durkheim: Terbiye ve Sosyoloji dersi okutulmaktadır (Talebe Kılavuzu, 1936:47-49). 1954 y1lında ise İstanbul Üniversitesi Edebiyat, Hukuk ve İktisat Fakültelerinde sosyoloji kürsüleri bulunmaktadır (Ülken, 1954:66). Bu tarihten itibaren de Edebiyat Fakültesi sosyoloji programlarında sosyolojinin alt disiplinlerine yönelik dersler bulunurken eğitim sosyolojisi dersi yer almamaktadır. ${ }^{9}$ Sosyoloji kürsüsü, 10 Ağustos 1961 tarih ve 10877 sayılı Resmi Gazetede yayınlanan "İstanbul Üniversitesi Edebiyat Fakültesi Lisans Öğretim ve İmtihan Yönetmeliği”yle, Edebiyat Fakültesinin 16 bölümünden biri olarak bağımsız bir bölüm kimliğine kavuşmuştur. Sosyoloji Bölümü, Umumi Sosyoloji ve Tecrübi Sosyoloji diye iki sertifikaya ayrılmıştır Bu düzenlemeyle Felsefe, Psikoloji, Pedagoji de ayrı birer bölüm haline gelmiştir (Resmi Gazete, 1961:4858). 24 Şubat 1983 tarih ve 17969 sayılı Resmi Gazetede yayınlanan yönetmelikte ise, sosyoloji bölümünün 45 lisans dersi arasında eğitim sosyoloji dersi yer almamaktadır (Resmi Gazete, 1983:60-61). 2020 yılı itibariyle İstanbul Üniversitesi Edebiyat Fakültesi bünyesindeki Sosyoloji Bölümünde dört anabilim dalı (Genel Sosyoloji ve Metodoloji, Kurumlar Sosyolojisi, Uygulamalı Sosyoloji ve Sosyometri ana bilim dalları) bulunmaktadır. Bölümün web sayfasında Kurumlar Sosyolojisinin aile, iktisat, siyaset, din gibi toplumsal kurumları ele alan çalışmaların yürütüldüğü bir ana bilim dalı olduğu ve sosyolojinin bu alt dallarına dair derslerin genellikle bu anabilim dalı tarafından yürütüldüğ̈̈; Uygulamalı Sosyolojinin ise sosyal sorunlara yönelik hazırlanan çalışmaların yapıldığı bir ana bilim dalı olduğu belirtilmektedir (https://sosyolojiedebiyat.istanbul.edu.tr, 2020).

Eğitim bilimlerine ve sosyolojiye ilişkin gelişmelerden diğeri ise Ankara Üniversitesi’ne bağl1 Dil ve Tarih-Coğrafya Fakültesi'nin (DTCF) kurulmasıdır. 23.03.1939 tarihinde kabul edilen “Ankara Dil, Tarih, Coğrafya Fakültesi Esas Talimatnamesi”ne göre Fakülte programı 16 disiplinden oluşmaktadır ve her bir disiplinde lisans ve doktora derecelerinde sınav yapılmaktadır. ${ }^{10} \mathrm{Bu}$ disiplinlerden biri olan Felsefe, zümre adıyla 1941-1942 ders y1lında, Umumi Felsefe ve Felsefe Tarihi, Psikoloji ve Pedagoji ile Sosyoloji olarak üç şubeye ayrılmaktadır. Sosyoloji öğretimindeki konular arasında köy sosyolojisi ve şehir sosyolojisi konuları bulunurken eğitim sosyolojisi konu olarak da yer almamaktadır (Talebe Rehberi,1942:45-48). Başlangıçtaki felsefe disiplini / zümresi ${ }^{11}$,

\footnotetext{
829 Mayıs 1932 tarihli raporunda Albert Malch 12 sabit kürsü önermektedir. Bunlardan biri Felsefe Tarihi, Umumi Psikoloji kürsüsü, diğeri İçtimaiyat, Ahlak, Terbiye kürsüsü olup, oldukça geniş bir kürsü yapılanması söz konusudur. Bununla birlikte raporda, sosyolojinin fakültede temsil edildiği ve bu nokta üzerinde ssrar etmemekle beraber, az çok yakın bir gelecekte fakültede bir ulûmu içtimaiye ve iktisadiye şubesi tesisi gerekeceği ve bu şubenin başarısı durumunda yeni bir fakülte olacağı belirtilmektedir. Albert Malch, İstanbul Üniversitesi Hakkında Rapor, İstanbul, Devlet Basımevi 1939, s. 43-52.

${ }^{9}$ Edebiyat Fakültesi Sosyoloji Bölümünün ders listesi için Bk. Yalvaç, a.g.e. s.282-306.

10 23.03.1939 tarih ve 40 ve 41 sayılı Maarif Vekilliği Kültür Kurulu kararı.

${ }^{11}$ DTCF'nin 1939 tarihli ilk talimatnamesinde disiplin kavramı kullanılmasına karşın, 1940 yılından itibaren bu disiplinler, resmi yazışmalarda enstitü olarak da yer almaktadır. Ayrıntılı bilgi için bk. Osman Kafadar (1998). Türkiye'de Yükseköğretimde Felsefe Eğitimi -Tarihsel Gelişim ve Lisans Eğitiminin Bir İncelemesi. Ankara Üniversitesi Sosyal Bilimler Enstitüsü. Yayımlanmış Doktora Tezi, s.230.
} 
1965-1966 yılında bölüm haline gelir, kendisine bağlı ders şubeleri / kürsüleri de Sistematik Felsefe, Felsefe Tarihi, İlim Tarihi, Sosyoloji, Psikoloji-Pedagoji Kürsüleri olarak yeniden düzenlenir (Ankara Üniversitesi, 1967:20). Fakültenin Psikoloji ve Pedagoji Kürsüsü, 31 Temmuz 1970 tarih ve 13565 sayılı Resmi Gazetede yayınlanan yönetmelikle öğretmenlik pedagoji formasyonu sertifikası vermekle yükümlüdür ve bu sertifika programındaki derslerden biri eğitim sosyolojisi dersidir (Resmi Gazete, 1970:5). Aytaç (2010)'a göre Psikoloji ve Pedagoji Kürsüsü, 14.05.1974 tarihinde, iki ayrı kürsü olarak yapılandırılmıştır. 1981 yılında DTCF'deki 45 kürsüden 6's1 (Pedagoji, Psikoloji, Sosyoloji, Bilim Tarihi, Felsefe Tarihi, Sistematik Felsefe) Felsefe Bölümü içerisindedir. Bu kürsü programlarının tamamında pedagoji dersi bulunmakta, Pedagoji Kürsüsünün içerisinde de bu kürsüye ait eğitim sosyolojisi dersi yer almaktadır. Sosyoloji Kürsüsünde ise örgüt sosyolojisi, sanayi sosyolojisi, sanat ve kültür sosyolojisi dersleri yer alırken, eğitim sosyolojisi bu kürsünün dersleri arasında yer almamaktadır. ${ }^{12}$ DTCF Sosyoloji Kürsüsü, bölüm web sayfasınaki bilgilere göre, 1983 yılında bağımsız bölüm kimliğine kavuşmuştur. 2020 itibariyle DTCF Sosyoloji Bölümü, Genel Sosyoloji ve Metodoloji, Kurumlar Sosyolojisi, Uygulamalı Sosyoloji ile Toplumsal Yap1 ve Değişme anabilim dallarından oluşmaktadır (http://sosyoloji.humanity.ankara.edu.tr, 2020).

1956 y1lında kurulan Orta Doğu Teknik Üniversitesi'nde sosyoloji ve psikoloji olmak üzere iki kürsüden oluşan Sosyal Bilimler Bölümünde ise eğitim sosyolojisi yer almamaktadır. 1957 yılında kurulan Hacettepe Üniversitesi'nde ise Tip ve Sağlık Bilimleri Fakültesine bağlı olan Temel Bilimler Yüksekokulu'nda ise lisans programındaki öğrencilerin derslerinin 2/3'ü sosyal bilimler, 1/3'ü fen bilimleri alanındandır. Hem bu derslerden biri hem de öğretmenlik sertifikası programının yedi zorunlu dersinden biri eğitim sosyolojisidir (Ankara Üniversitesi, 1967:7-19).

\section{Enstitüler}

İstanbul Üniversitesi'nde, 1933-1934 ders y1lında, önce iktisadi ve içtimai sahada araştırma yapmak üzere Hukuk Fakültesi'ne bağlı olarak kurulan İktisat ve İçtimaiyat Enstitüsü, 1936 yılında İktisat Fakültesi kurulunca bu fakülteye bağlanır. Fakültede sosyal siyaset, iktisat, işletme, maliye, iktisat tarihi disiplinleri ve bu disiplinlerin içinde de kürsüler yer almaktaydı. İktisat disiplininde Sosyal Siyaset, İktisat ve İşletme Kürsüleri; Sosyal Siyaset Kürsüsünde ise sosyoloji ve sosyal siyaset sahaları bulunmaktaydı. Bu iki şube 1961 yılında ayrı kürsü olarak yer almıştır (Talebe Rehberi,1936:23; Zaim, 2007:322-330; İktisat Fakültesi, 1955:3-4). 1949 y1lında Enstitü, İçtimaiyat Enstitüsü şeklinde adlandırılmış ve Enstitünün bir özelliği, Gökalp'in kürsüsünden ve enstitüsünden ayrılan bir yönü olan iktisadi sorunlara merkezi önem vererek, sosyal siyaset alt disiplinine bağlı kalması (Özcan, 2010:125) olmuştur. İktisat Fakültesi'nde Sosyoloji ve Sosyal Siyaset Enstitüsü'nün dersleri ve disiplinleri ise sosyoloji, metodoloji, sosyal siyaset, kooperatifçilik, komün bilgisidir. İlk ikisi nazari (kuramsal), diğerleri ise ameli ve tatbiki (uygulamalı) mahiyettedir. Enstitü Talimatnamesine göre Enstitünün gayesi, içtimai ve iktisadi bilgilere ait araştırmalar yapmak, memleket ve cihan iktisat ve içtimaiyat meselelerine ait neşriyatı, vesikaları ve malumatı toplamak, bunları tahlil ve tasnif etmek, halk arasında içtimai ve iktisadi bilgileri yaymaktır. Bu çerçevede Enstitü, memleketi tanıma ve tanıtma seyahatleri, halk için içtimai konferanslar, bu konferanslarla ilgili kitapları neşretme gibi faaliyetlerin yanı sıra, çeşitli sosyal meselelerle ilgili olarak da anketler ${ }^{13}$ düzenlemiş ve kurumlara raporlar hazırlamıştır (Talebe Rehberi, 1936:23; İktisat Fakültesi, 1955:341). Hukuk ve İktisat Fakültelerindeki sosyoloji öğretimi ve Enstitülerinden başka fonksiyonlarla donatılmış olması gereken bir Sosyoloji Enstitüsü olması gerekliğine inanan Prof. Hilmi Ziya Ülken,

\footnotetext{
${ }^{12}$ Bk. Musa Çadırcı ve Azmi Süslü, Ankara Üniversitesi Gelişim Tarihi. Ankara Üniversitesi Basımevi, 1982, s.177-218.

${ }^{13} \mathrm{Bu}$ anketler İstanbul'daki öğrenci yurtlarında kalan öğrencilerin yaşayış tarzı, dar gelirli bazı memur tabakalarının aile bütçeleri, İstanbul küçük sanayiinin bugünkü durumu, Soyadı Kanunu'nun bazı ilerdeki tatbikatı, İstanbul tramvay işçilerinin içtimai durumu, Türkiye'de işçi sendikalarının bugünkü durumu, Yemin müessesesi, Bulgaristan Türklerinin son tehciri ve Türkiye'de iskânı hakkında anketlerdir. Ayrıca 1936'da kabul edilen İş Kanunu'nun düzenlenmesinde Enstitünün büyük katkısı olmuştur. Bk. İktisat Fakültesi, İçtimaiyat Enstitüsü Hakkında Kuruluşunun XX. Yılı Münasebetiyle Rapor (1934-1954), İstanbul, 1955, s. 22-24.
} 
Edebiyat Fakültesi Sosyoloji Enstitüsü'ne ilişkin bir layiha hazırlar. Bu layihada, metodoloji, sosyoloji tarihi, morfoloji ve demografya, dini, ahlaki, hukuki, bedii (güzellik,estetik) sosyolojiler, dil, sanat ve bilgi sosyolojileri, köy, kasaba, şehir gibi zümrelerin münasebetini tetkik eden ekolojinin sosyolojinin esaslı dallarını teşkil ettiği belirtilir (İktisat Fakültesi, 1955:40). Bu Enstitü, 13 Haziran 1960 tarih ve 10524 sayılı Resmi Gazetede yayınlanan İstanbul Üniversitesi Edebiyat Fakültesi Sosyoloji Enstitüsü Talimatnamesi ile Edebiyat Fakültesi bünyesinde yer alır. Bu yönetmeliğe göre Enstitünün amacı ve görevleri, memleketin hal ve mazisini sosyoloji metodlarına göre tetkik etmek, diğer üniversite ve fakültelerle ilmi ve mesleki teşekküllerle işbirliği yapmak, kendi sahasına ait her türlü neşriyatta bulunmaktır (Resmi Gazete, 1960:1517). Edebiyat Fakültesinde kurulan Sosyoloji Enstitüsü, Ülken tarafindan Gökalp'in kurduğu İçtimaiyat Darülmesaisi'nin devamı olarak nitelendirilse de, yeni bir sosyoloji enstitüsü olarak kurulmuştur (Yalvaç, 2010:285). Daha sonra Sosyoloji Enstitüsü, 22 Nisan 1976 tarih ve 15567 sayılı İstanbul Üniversitesi İktisat Fakültesi Sosyoloji Enstitüsü Hakkında Yönetmeliği ile İktisat Fakültesi'nde kurumsal gelişimini sürdürür (Resmi Gazete, 1976:5). Bu yeni düzenlemeyle sosyolojinin, hem Edebiyat hem de İktisat Fakültesi’nde ayrı ayrı iki Sosyoloji Enstitüsü olarak gelişimini devam ettirdiği söylenebilir. Kaldı ki bu durum, Kaçmazoğlu (2010:218)'nun belirttiği İstanbul ekolündeki iki farklı anlayışın Edebiyat Fakültesi'nde Hilmi Ziya Ülken'le, İktisat Fakültesin'de de Ziyaeddin Fahri Findıkoğlu ile temsiliyetinin bir yansıması olarak değerlendirilebilir.

Eğitim bilimlerine ilişkin gelişmelerden biri ise 1936'da İstanbul Üniversitesi Edebiyat Fakültesi bünyesinde Pedagoji Enstitüsü'nün kurulmasıdır. Enstitü, Edebiyat ve Fen Fakülteleri öğrencilerinden lise öğretmeni olmak isteyenlere kendi dallarında aldıkları bilgilerin yanında pedagojik formasyon vermektedir. Enstitünün amacı, Pedagoji ve Tecrübi Psikoloji öğretmek ve araştırmalar yapmaktır (Talebe Kılavuzu, 1937:24; Uğurel-Şemin, 1973). 1967 yılında ise Eğitim bilimlerine ilişkin Edebiyat Fakültesi'ne bağlı Pedagoji Enstitüsü ile Psikoloji Enstitüsü bulunmaktadır. Pedagoji Enstitüsünün, dört sertifika programı bulunmaktadır. Bu programda pedagoji ve sosyoloji zorunlu dersleri arasındadır. Lisansüstü çalışmalar ise Psikoloji Enstitüsünde yürütülmektedir (Ankara Üniversitesi, 1967:3-5).

Eğitim sosyolojisi açısından diğer bir gelişme ise, 5-14 Şubat 1953 tarihlerinde gerçekleştirilen Beşinci Milli Eğitim Şûrası'dır. Burada alınan kararlara göre, Öğretmen okulları ile Köy Enstitülerinin programlarına, okul ile çevre arasındaki ilişkinin güçlendirilmesi, öğretmenin sosyal çevresi içinde ilgili ve verimli olmasını sağlamayı hedeflemesi bakımından, "nazarî (teorik) bir sosyoloji biliminden ziyade meseleleri pragmatik bir görüşle ele alan" eğitim sosyolojisi dersi konulur (Maarif Vekâleti, 1953:577).

\section{Dergiler}

Darülfünun İçtimaiyat Darülmesaisi tarafindan 1917 yılında 6 sayı yayınlanan İçtimaiyat mecmuas1, 1942'den itibaren Sosyoloji Dergisi adıyla 1942-1968 yıllarında 22 sayı, 1989-2005 yılları arasında 11 sayı yayınlanmıştır (Ercan, 2013:21). 2006'dan 2019 Haziran ayına kadar ise 27 sayı çıkarmıştır. Derginin ilk döneminde (1917) sadece Durkheim'in "İlm-i Terbiye ve İçtimaiyat" başlıklı yazısının çevirisi; ikinci döneminde (1942-1968) Ülken'in "Milli Eğitim Bakanlığı Yüksek Makamına" başlıklı bir dilekçesi ve sosyoloji ve felsefe öğretmenlerinin karşılaştıkları sorunları anlatan "Sosyolojide yeni adımlar" başlıklı makalesi ile Muzaffer Sencer'in "Sosyolojik açıdan Türkiye'de ilköğretim" başlıklı makalesi; üçüncü döneminde (1989-2005) ders kitapları ve okumayazma ile ilgili kitap incelemesi, eğitimde batıllış̧ma ve polis akademisi öğrencilerinin sosyoekonomik geçmişlerine ilişkin makaleler (Ercan, 2013:44-191) dişında eğitim sosyolojisi çalışması olarak nitelendirilebilecek makale/yazı yer almamaktadır. Benzer biçimde, 2006'dan 2019 Haziran ayına kadar yayınlanan sayılarında da bu durum değişmemiştir.

Üniversite çatısı altında eğitim bilimlerine ilişkin ilk dergi, 1968 yılında yayınlanmaya başlayan Ankara Üniversitesi Eğitim Fakültesi dergisidir. Miser'e (2016:219) göre bu dergi, 1982 
yılından 1997 yılına kadar "Eğitim Bilimleri Fakültesi Dergisi”, bu tarihten itibaren ise "Ankara Üniversitesi Eğitim Bilimleri Fakültesi Dergisi” adıyla yayımlanmaya devam etmiştir. Dergide 2020 yılı Ocak ayı itibariyle yayınlanan makale sayısı 1474'tür. Bu makalelerden eğitim sosyolojisine ilişkin kuramsal ve uygulamalı makale sayısının oldukça fazla sayıda olduğu söylenebilir.

\section{Eğitim Sosyolojisinin Bağımsızlığı}

1964 y1lında Ankara Üniversitesi'ne bağlı olarak kurulan Eğitim (Bilimleri) Fakültesi'nin 23 Ağustos 1965 tarihli ilk lisans yönetmeliğine göre Fakülte sekiz kürsüden oluşmaktadır (Resmi Gazete, 1965:7). Bu kürsülerden biri de eğitim sosyolojisi kürsüsüdür. Günümüz akademik örgütlenmesinde bölümlere karşılık gelen Fakültenin kürsü yapısının, eğitim sosyolojisi için de milat olduğu söylenebilir ve bu disiplinin üniversitede bağımsız bir birim olmasının başlangıcı olarak kabul edilebilir. $\mathrm{Bu}$ ilk yapılanmada Eğitim Sosyolojisi Kürsüsü'nün dersleri tablo 1'de gösterilmektedir.

Tablo 1: Ankara Üniversitesi Eğitim Fakültesi Eğitim Sosyolojisi Kürsüsü dersleri (1965)

\begin{tabular}{ll} 
Kürsü & Dersleri \\
\hline \multirow{2}{*}{ Eğitim Sosyolojisi Kürsüsü } & Genel Sosyoloji \\
& Eğitim Sosyolojisi \\
& Sosyoloji Doktrinleri Tarihi \\
& Sosyal Antropoloji \\
\hline
\end{tabular}

22 Kasım 1967 tarih ve 12757 sayılı Resmi Gazetede yayımlanan yönetmelik değişikliğiyle, Eğitim Sosyolojisi (ES) Kürsüsüne bağlı ders sayısı diğer kürsülerden dersler alınarak Tablo 2'de görüldüğü üzere 4'ten 10'a çıkarılmıştır.

Tablo 2: Eğitim Sosyolojisi Kürsüsü ve dersleri (1967)

\begin{tabular}{ll}
\hline Kürsü & Dersleri \\
\hline & Genel Sosyoloji \\
& Eğitim Sosyolojisi \\
& Sosyoloji Teorileri \\
& Sosyal Antropoloji \\
& Toplum Kalkınması \\
Eğitim Sosyolojisi Kürsüsü & Halk Eğitimi \\
& Eğitim İdaresinde Beşeri \\
& Münasebetler \\
& Sosyal Bilimlerde Araştırma \\
& Metodları \\
& Sosyal Psikoloji \\
& Çocuk Suçluluğu ve Suçlu \\
& Çocuklarn Eğitimi (Islah) \\
\hline
\end{tabular}

24 Mayıs 1969 tarih ve 13206 sayılı Resmi Gazetede yayımlanan yönetmelikle Eğitim Sosyolojisi Kürsüsü’ne bağlı derslerden olan Eğitim İdaresinde Beşeri Münasebetler dersi, Eğitim 
İdaresi ve Planlaması Kürsüsü’ne bağlı, Eğitimde İdari Davranış dersi olarak yer almıştır. Ayrıca Eğitim Tarihi ile Türk Eğitim tarihi dersleri Eğitim Sosyolojisi Kürsüsü’ne bağlı dersler arasında yer alarak, kürsüdeki ders sayısı 11'e çıkmıştır. Fakültedeki bu düzenlemenin yanı sıra 17 Ekim 1969 tarih ve 13329 sayılı Resmi Gazetede yayımlanan Ankara Üniversitesi Eğitim Fakültesi Lisans-Üstü Öğretim ve Sınav Yönetmeliğiyle, Ankara Üniversitesi Eğitim Fakültesi'nin kürsülerinden her biri, "Yüksek Eğitim Lisansı" ve "Eğitim Doktorası" derecelerini veren bir "Lisans-Üstü öğretim alanı"nı temsil etmektedir. Dolayısıyla, fakültede bu tarihten itibaren lisansüstü eğitimin başlamasıyla, Eğitim Sosyolojisi Kürsüsü'nün lisansüstü eğitim sürecinin de başladığı söylenebilir. Buna göre Fakültedeki Eğitim Sosyolojisi Kürsüsü ve bağlı dersleri tablo 3 'te yer almaktadır.

Tablo 3: Eğitim Sosyolojisi Kürsüsü ve bağlı dersleri (1969)

\begin{tabular}{ll}
\hline Kürsü & Dersleri \\
\hline & Genel Sosyoloji \\
& Eğitim Sosyolojisi \\
& Sosyoloji Teorileri \\
& Sosyal Antropoloji \\
Eğitim Sosyolojisi Kürsüsü & Toplum Kalkınması \\
& Halk Eğitimi \\
& Sosyal Bilimlerde Araştırma Metodları \\
& Sosyal Psikoloji \\
Çocuk Suçluluğu ve Suçlu Çocukların & Eğitimi (Islah) \\
& Eğitim Tarihi \\
& Türk Eğitim Tarihi \\
\hline
\end{tabular}

20 Temmuz 1971 tarih ve 13901 sayılı yönetmelik değişikliğiyle, Eğitim Sosyolojisi Kürsüsü'ne bağlı ders sayısı 10'dan 13'e çıkarılmış, Sosyoloji, Eğitim Tarihi ve Türk Eğitim Tarihi dersleri ise iki dönem olacak biçimde düzenlenmiştir. Eğitim Sosyolojisi Kürsüsü, 1974 yapılanmasında Eğitimin Sosyal ve Tarihi Temelleri (ESTT) Bölümü adını almıştır. Eğitim Felsefesi Kürsüsü, Fakülte Kurulunun aldığı bir kararla, 1979 yılında Eğitim Sosyolojisi Kürsüsü ile birleşerek Eğitimin Sosyal ve Tarihi Temelleri Bölümünün içerisinde yer almıştır (Miser, 2016:147; Aslan, 2019:419). 16 Ekim 1980 tarih ve 17137 say1l, Ankara Üniversitesi Eğitim Fakültesi Lisans-üstü Eğitim ve Sınav Yönetmeliğinin 2/b maddesinde yapılan değişiklikle, lisans tamamlama programında lisans-üstü eğitim komisyonu kararıyla bütün bölümlerin tamamlama programında 6 ders zorunlu ders olarak okutulmuştur. Bu derslerden ikisi Eğitimin Sosyal ve Tarihi Temelleri Bölümü (ESTT) bünyesindeki Eğitim Sosyolojisi ve Türk Eğitim Tarihi dersleridir. 1980-1981 ders yılında ESTT'nin 16 dersinden bazıları sosyoloji, eğitim tarihi, Türk eğitim tarihi, köy sosyolojisi, eğitim antropolojisi, eğitim felsefesi ve eğitim sosyolojisi dersleridir. ${ }^{14}$ ESTT'nin temel derslerinden, ögretmen yetiştiren programlarda zorunlu ders olan eğitim sosyolojisi ve eğitim tarihi dersleriyle birlikte, eğitim felsefesi dersi 1997 yılında Eğitim Fakültelerinin ve Ankara Üniversitesi Eğitim Bilimleri Fakültesinin lisans programlarından kaldırılmış, 2016 düzenlemesiyle birlikte bu üç temel dersi öğretmenlik programlarının tamamında tekrar zorunlu dersler arasında yer almıştır. Tablo

${ }^{14}$ 17.03.1980 tarihli Ankara Üniversitesi Eğitim Fakültesi Fakülte Kurulu kararı. 
4'te eğitim sosyolojisi disiplininin üniversitedeki akademik örgütlenmesinin tarihsel serüveni yer almaktadır.

Tablo 4: Eğitim Sosyolojisinin Tarihsel Serüveni (1965-2020)

\begin{tabular}{|c|c|c|c|c|}
\hline Yil & Kürsü & Bölüm & $\begin{array}{l}\text { Anabilim } \\
\text { Dalı }\end{array}$ & $\begin{array}{l}\text { Bilim } \\
\text { Dal1 }\end{array}$ \\
\hline 1965 & $\begin{array}{c}\text { Eğitim } \\
\text { Sosyolojisi }\end{array}$ & & & \\
\hline 1974 & & $\begin{array}{l}\text { Eğitimin } \\
\text { Sosyal ve } \\
\text { Tarihi } \\
\text { Temelleri }\end{array}$ & & \\
\hline $\begin{array}{c}1982 \\
- \\
1996\end{array}$ & & $\begin{array}{l}\text { Ĕ̆itim } \\
\text { Programları } \\
\text { ve Öğretim } \\
\text { Bölümü }\end{array}$ & $\begin{array}{l}\text { Eğitimin } \\
\text { Sosyal ve } \\
\text { Tarihi } \\
\text { Temelleri }\end{array}$ & \\
\hline 1997 & & $\begin{array}{l}\text { Eğitim } \\
\text { Bilimleri } \\
\text { Bölümü }\end{array}$ & $\begin{array}{l}\text { Eğitim } \\
\text { Programları } \\
\text { ve Öğretim }\end{array}$ & $\begin{array}{l}\text { Eğitimin } \\
\text { Sosyal ve } \\
\text { Tarihi } \\
\text { Temelleri }\end{array}$ \\
\hline $\begin{array}{c}2007 \\
- \\
2015\end{array}$ & & $\begin{array}{l}\text { Eğitimin } \\
\text { Kültürel } \\
\text { Temelleri } \\
\text { Bölümü }\end{array}$ & $\begin{array}{l}\text { Eğitimin } \\
\text { Sosyal ve } \\
\text { Tarihi } \\
\text { Temelleri } \\
\end{array}$ & \\
\hline $\begin{array}{c}2016 \\
-\end{array}$ & & $\begin{array}{l}\text { Eğitim } \\
\text { Bilimleri } \\
\text { Bölümü }\end{array}$ & $\begin{array}{l}\text { Eğitimin } \\
\text { Felsefi, } \\
\text { Sosyal ve } \\
\text { Tarihi } \\
\text { Temelleri }\end{array}$ & \\
\hline
\end{tabular}

1965 yılında bağımsız bir kürsü olan eğitim sosyolojisi, 1974 yılından 1982 yılına kadar ESTT Bölümü olarak varolmuştur. Bu süreçte ESTT'nin 4 bilim dalı sosyoloji, eğitim sosyolojisi, felsefe tarihi ve eğitim felsefesidir. ${ }^{15}$ ESTT 1983, 1989 ve 1995 Fakülte yapılanmasında Eğitim Programları ve Öğretimi Bölümünün bir anabilim dalına dönüşmüştür. 1983 tarihinde ESTT Ana Bilim Dalının bilim dalları ise eğitim sosyolojisi, eğitim felsefesi, Türk eğitim tarihi ve eğitim tarihidir. ${ }^{16}$ ESTT Ana Bilim Dalının bağlı olduğu Eğitim Programları ve Öğretimi Bölümü, 1997 yapılanmasında Eğitim Bilimleri Bölümünün bir anabilim dalına dönüşünce, ESTT de bilim dalı konumuna gerilemiştir. Yükseköğretim Genel Kurulu'nun 11.07.2007 günlü toplantısında aldığı kararla ESTT, Eğitim Felsefesi (EF) Ana Bilim Dalı ile birlikte Eğitimin Kültürel Temelleri Bölümü içerisinde yeniden yapılandırılmıştır. Bu iki ana bilim dalı (EF-ESTT), 2016 yılında eğitim fakültelerinin yeniden yapılandırılması kapsamında, Eğitim Bilimleri Bölümünün altında Eğitimin Felsefi, Sosyal ve Tarihi Temelleri (EFSTT) adı ile tek bir ana bilim dalına dönüşmüştür. ${ }^{17}$

\footnotetext{
15 05.10.1981 tarihli Ankara Üniversitesi Eğitim Fakültesi Fakülte Kurulu kararı.

${ }^{16}$ 28.03.1983 tarihli Ankara Üniversitesi Eğitim Fakültesi Fakülte Kurulu kararı.

17 EFSTT'nin dört uzmanlık alanı Eğitimin Sosyal ve Tarihi Temelleri, Eğitim Sosyolojisi, Eğitim Tarihi ve Eğitim Felsefesi, Eğitim Bilimlerinde doçentlik alanları arasındadır. Bk. http://www.uak.gov.tr.
} 


\section{Eğitim sosyolojisinin lisansüstü serüveni}

Eğitim sosyolojisi disiplini, Ankara Üniversitesi, Eğitim (Bilimleri) Fakültesi’nde 1969 tarihinden 1974 yılına kadar kendi adıyla, bu tarihten itibaren Eğitimin Sosyal ve Tarihi Temelleri (ESTT) programı içerisinde lisansüstü eğitimlerine devam etmektedir. Eğitim sosyolojisinin lisansüstü eğitimleri, 2016 yılından itibaren Eğitimin Felsefi, Sosyal ve Tarihi Temelleri (EFSTT) programı adı altında Ankara Üniversitesi, Gazi Üniversitesi ve Samsun On Dokuz Mayıs Üniversitesi Eğitim Bilimleri Enstitülerinde yürütülmektedir. EFSTT programı, Ankara Üniversitesi Eğitim Bilimleri Enstitüsü ve Samsun On Dokuz Mayıs Üniversitesi'nde hem yüksek lisans hem de doktora programıyla, Gazi Üniversitesi'nde sadece yüksek lisans programıyla yürütülmektedir. Ayrıca, Ankara Üniversitesi Eğitim Bilimleri Enstitüsü'nde eğitim-öğretim dili İngilizce olan, Uluslararası Eğitim Sosyolojisi Tezli Yüksek Lisans Programı da bulunmaktadır. Eğitimin Sosyal ve Tarihi Temelleri programı, Samsun On Dokuz Mayıs Üniversitesi’nde 2009 yılında; Gazi Üniversitesi'nde, YÖK'ün 18.08.1998 tarih ve 18357 sayılı kararıyla, Eğitim Bilimleri Enstitüsü’nde tezli yüksek lisans programıyla, yüksek lisans düzeyinde eğitim vermeye başlamıştır.

\section{Sonuç ve Tartışma}

Sosyoloji biliminin öncülerinin, eğitimle ilgili konuları ele almış olmalarına karşın "sosyoloji ile "eğitim bilim" arasındaki köprünün geç bir dönemde kurulduğu söylenebilir. Bu çerçevede eğitim sosyolojisinin akademilerde bağımsız bir alt-disiplin olarak 20. yüzyılın ortasından itibaren yer bulduğu görülmektedir. Kuşkusuz böylesi bir gecikme, Tan (1981:28)'a göre, toplum bilim ile eğitim bilimin amaç ve nitelik ayrılıklarından, toplumbilimin neden-sonuç ilişkilerini araştıran kuramsal, eğitim biliminin ise pratik sonuçlara önem veren uygulamalı bilimler olmasından kaynaklanmaktadır.

Türkiye'nin ilk sosyologlarına göre toplumsal sorunları çözmede sosyoloji, anahtar rolünde olup bu anahtar aracılı̆̆ıyla tüm sorunların çözüleceği anlayışının hakim olduğu söylenebilir. Bu bakış açısından, sosyolojinin nesnesi toplumsal yap1 ve öğeleridir. Benzer biçimde dönemin eğitimcilerinden Baltacioğlu (1998:124) "terbiyenin fert üzerinde mutlak tesiri” olduğu, terbiye düzelince her şeyin birden düzeleceği ve terakkinin (ilerlemenin) mebdeinin (başlangıcı) terbiye olduğu anlayışının hakim olduğunu belirtmektedir. ${ }^{18}$ Bu bakış açısından ise eğitimin başlıbaşına bilimsel yöntemler işe koşularak yeni toplumu inşa etmede anahtar rolünde olduğu, eğitim düzeltilirse tüm toplumsal sorunların çözüleceği anlayışının varlı̆̆ı, eğitimin de ayrı bir bilim alanı olarak ele alındığının düşünsel ve politik göstergeleri olarak kabul edilebilir. Bu çerçevede sosyolojinin iddiası, nesnesi olan toplumsal yapı ve öğelerindeki sorunları çözmek iken eğitimin de iddiası, içinde bulunduğu yapının ve öğelerindeki sorunların çözümüne yöneliktir. Dolayısıyla birinci durumda nesne olan eğitim, ikinci durumda özne konumundadır.

Akademik disiplinler, sıklıkla kendine özgü biçimde kurumsal uygulamaların yer aldığı ve araştırmaların yapıldığı epistemolojik yapılar olarak ele alınırlar (Lauder vd., 2011:14). Bu yönüyle sosyoloji biliminin kurumsallaşmasında, hem enstitü hem de kürsü ve dersleriyle başlangıçta İstanbul'da Edebiyat Fakültesinde, üniversite reformuyla birlikte Hukuk, Edebiyat ve İktisat Fakültelerinde, Ankara'da 1940'tan itibaren DTCF'de, sonra da Gökçe (1994:3)'ye göre ODTÜ, Hacettepe, Boğaziçi ve Ege Üniversitelerinde felsefe kürsüleri, sosyal bilimler ve davranış bilimleri içinde gelişerek bağımsız bir bölüm haline gelmiştir. Eğitim sosyolojisinin, Türkiye'de başlangıcından günümüze İstanbul Üniversitesi'nde başta Edebiyat Fakültesi olmak üzere diğer fakültelerde ve Ankara Üniversitesi DTCF’deki ve diğer üniversitelerdeki Sosyoloji Bölümlerinin akademik örgütlenmesinde, enstitülerinde, araştırmalarında, yayınlarında varlığına ve gelişimine ilişkin kanıtlar ileri sürmek zordur. $\quad 1910$ 'da Darülfünun'dan, İstanbul Üniversitesi Edebiyat

\footnotetext{
${ }^{18}$ Aslında Baltacıoğlu bu anlayışı eleştirmekle birlikte, eğitimin bilimsel esaslar çerçevesinde ele alınması gerektiğini ve bunun önemini vurgulamaktadır.
} 
Fakültesi Sosyoloji Bölümü'nde 1982'ye kadar ders programında yaklaşık 113 tane ders yer almaktadır. ${ }^{19}$ Bu ders listesinde eğitim sosyolojisi dersi yer almamaktadır. ODTÜ'de Sosyal Bilimler Bölümünde 60 dersten biri sosyolojiye giriş dersidir ve eğitim sosyolojisi dersi yer almamaktadır. Hacettepe Üniversitesi Temel Bilimler Yüksekokulunda öğretmenlik sertifikası programının yedi zorunlu dersinden biri eğitim sosyolojisidir (Ankara Üniversitesi, 1967:7-18). Bununla birlikte Edebiyat Fakültesi'nde 1961'de, DTCF'de 1983'te bağımsız bir bölüm haline gelen Sosyoloji Bölümünün lisans ders programlarında da eğitim sosyolojisi dersi yer almamaktadır. Bunun yanı sıra günümüz sosyoloji lisans programlarının ders çizelgelerine bakıldığında da eğitim sosyolojisi dersinin yer almadığı görülebilir. Bu tespitlerden hareketle, Türkiye'de sosyolojinin bir alt disiplini olarak kabul edilen eğitim sosyolojisine ilişkin herhangi bir dersin, herhangi bir akademik örgütlenmenin, çalışmanın sosyoloji bölümlerinin akademik gelişimlerinde, gündemlerinde ve programlarında olmadığı söylenebilir.

Türkiye'de sosyolojinin iki ana damarı olarak kabul edilen, "Batı sosyolojisinin izleyiciliğine koşulmuş "uyumcu" sosyoloji anlayışı ile gelişmekte olan ve kendisine meşru bir zemin açmaya çalışan, kendi kök ve kaynaklarına bağl1, Batı sosyolojisini sorgulayıp direnç gösteren "yerli" sosyoloji anlayışlarının" (Özcan, 2010:96) ya da Kıta Avrupası ve Amerikan sosyolojisi farklılaşmasının karşılığı olarak nitelendirilen Ankara ve İstanbul ekollerinin (Kaçmazoğlu, 2010:218) akademik gelişimlerinde ve gündemlerinde eğitim sosyolojisinin olmadığı söylenebilir. Bununla birlikte eğitim bilimleri alanında çalışan araştırmacıların Türkiye'de eğitim sosyolojisi disiplinini sosyolojiye doğurtma / yakınlaştırma çabalarına karşın, sosyologların da eğitim sosyolojisi çalışmalarına oldukça sınırlı sayıda yer vermesi ve sosyolojinin kurumsal gelişiminde bu disipline hiç yer vermemesi aslında ciddi bir meşruiyet krizi olarak nitelendirilebilir. Ayrıca Türkiye'deki sosyoloji lisans programlarında, sosyolojinin alt disiplinlerinin çoğunluğuna ilişkin dersler yer alırken, bir alt disiplini olarak kabul edilen eğitim sosyolojisinin ders olarak da yer almadığı, sosyologların eğitim sosyolojisini sahiplenmedikleri ve doçentlik alanı olarak kabul edilmesinin dışında gündemlerinde olmadığı söylenebilir. ${ }^{20}$ Elbette, sosyolojinin alt disiplinlerinin / özel alanlarının varlı̆̆ının reddi anlayışında eğitim sosyolojisinin yeri olamayacakken, alt disiplinlerinin yokluğu anlayışını kabul etmeyenler için de eğitim sosyolojisi gündemlerinde yer alamamıştır.

Uygulamalı sosyolojinin altın dönemi olarak nitelendirilen, 1950'den itibaren AngloAmerikan sosyolojisine özgü yaklaşımların, ABD'de yükseköğrenim görüp gelen genç DTCF hocaları, 1945 sonrasında ise Hacettepe Üniversitesi ve ODTÜ'de kurumsallaştığı, Kösemihal'le birlikte ampirik sosyoloji ve sosyometrik araştırmaların özendirildiği (Özcan, 2010:154-156) ve Ankara merkezli üniversitelerde (Ankara, ODTÜ, Hacettepe) açılan sosyoloji bölümlerinin dayandıkları sosyoloji anlayışlarının Amerikan sosyolojisi, daha genel ifade ile Anglo-Sakson bilim anlayış1 çerçevesinde biçimlendiği (Azman \& Yetim, 2010:256) belirtilse de, burada da eğitim sosyolojisinin varlığına ilişkin kanıtlar ileri sürmek zordur. Çelebi (2010:62) sosyologların ortak noktasının uygulamalı sosyoloji yapmaktaki isteksizlikleri olduğu tesbitinden sonra Türkçedeki "applied" terimi için kullanılan "uygulamalı" sözcüğünün sosyolojik bilginin sorun çözümü için uyarlanması tarzında anlaşılmayıp tersine, "uygulama"dan anlaşılanın, genel olarak "alan araştırması yapmak" olduğunu belirtmektedir. Kaçmazoğlu (1994:53), Türkiye'de Amerikan sosyolojisi anlayışını benimseyen sosyologların mikro ve dar alan araştırmalarına, Kıta Avrupası sosyolojisinin izlerini taşıyan ya da yerli bir sosyoloji anlayışını geliştirmeye çalışanların ise daha genel ve makro konulara yöneldiklerini belirtmektedir. Bu düşüncelere karşın İlyasoğlu (2001:96) sosyoloji alanında üretilen bilginin "ulusal", "yerli", evrensel", "küresel" türünden sıfatlarla ayrıştırılmasının, bu

\footnotetext{
${ }^{19}$ Ders listesi için bk. Yalvaç, a.g.e., s.302.

${ }^{20}$ Son birkaç yıldır sosyologların Eğitim Sosyolojisi adıyla üniversite ders kitabı yayınlamaları, eğitim sosyolojisine ilgilerinden daha çok, üniversite-piyasa eklemlenmesinin sonucu, arz-talep ilişkisinin bir yansıması olabileceği gibi, eğitim konularının popüler, moda, gündemde olan konular arasında olmasıyla da ilgili olabileceği söylenebilir.
} 
sıfatlar temelinde farklılıkların karşılıklı olarak kodlanmasının ötesine geçmek gerektiğini belirtmektedir. Bu durum aslında, Türkiye'de her düşünce döneminin, kendinden önceki dönemden önemli ölçüde etkilendiğinin, kendinden önceki dönemin getirdiği birikime karşı çıkmanın ya da tepki göstermenin neredeyse her dönemin vazgeçilmez bir özelliği (Kongar, 1993:17) olmasıyla açıklanabilir. Dolayısıyla Türkiye'de sosyoloji bilimi içerisinde eğitim sosyolojisinin varolamayışının ve gelişememesinin bir nedeninin de kendinden önceki dönemden etkilenmenin yeniden üretimi biçiminde ortaya çıkmasının sonucu olduğu söylenebilir.

Türk sosyolojisinde bu anlayışların gündeminde Türkdoğan (1996:511)'a göre, 1950-1970 döneminde köy ve kasaba araştırmaları ile modernleşme ve gelenekselleşme, 1970'ten sonra ise teorik perspektifte, arşiv kaynaklı belgesel incelemeler ve çeviriler yer almaktadır. Özcan (2010:185)'a göre Türk sosyolojisinin gündemi 1960 ve 1970'li y1llar boyunca iktisadi kalkınma sorunlarında yoğunlaşırken, 1980 'lerden itibaren ana eğilimin siyasal ve kültürel sorunlara (özellikle de İslam, demokratikleşme, devlet-toplum ve din-devlet ilişkileri konularına) kaydığ görülmektedir. Kuşkusuz bu durum toplumsal değişmenin, Türkiye'nin geçirdiği dönüşümlerin sonucu olarak değerlendirilebilir. Kaçmazoğlu (1994:55)'na göre de 1980-1991 döneminde Türkiye'de sosyoloji gündeminin kadın ve aile, kent ve Türk sosyoloji tarihi çalışmalarında yoğunlaştığı belirtilmektedir. Bunun yanı sıra Ülken (1941:14-17)'in sosyoloji incelemeleri sınıflandırmasında (ekonomik-politik, hukuki, ahlaki, bedii, fikri ve dini içtimaiyat) eğitime yer vermemesi, sosyolojinin gündeminin ne olduğunun bir göstergesidir. Bununla birlikte Türkiye'de eğitim sosyolojisinin sosyoloji içerisinde geliştiği (Doğan, 2018:71; İnal, 2014:11; Esgin, 2013:149) değerlendirmesinden ziyade, eğitimin ayrı bir bilim alanı olarak bilimsel yöntemle ele alınması ve incelenmesinin, dönemin terminolojisi içerisinde ilmi terbiye, fenni terbiye, terbiyevi içtimaiyat, pedagoji adı altında gerçekleştiği ve eğitim sosyolojisinin de bu çerçevede değerlendirilmesi gerektiği söylenebilir. Köymen (1953:I)'in eğitim sosyolojisinin doğuşunun sosyolojinin ve eğitimin doğuşu gibi sosyal değişmenin hızlanması sonucunda olduğu değerlendirmesiyle birlikte, eğitim sosyolojisini "eğitimin sosyal cephesini ve sosyolojinin eğitim cephesini birleştiren kesin maksatlı bir sentez ilimi” olarak tanımlaması da, bu yeni disiplinin 1950'lerdeki kaynaklarına ilişkin bir değerlendirmedir. Dolayısıyla toplumsal olan eğitimin, Türkiye'de toplumu inceleyen yeni bilim anlayışında, sosyolojide, bir karşılığının olmadığı ve bu iki alanın birbirinden ayrı bilim alanları olarak ele alındığı söylenebilir. Bununla birlikte eğitim sosyolojisinin eğitim bilimleri içerisinde konumlandırılmasının genelde sosyal bilimlerin, özelde ise sosyolojinin yöntem, alg1 ve tahlil zenginliklerinden koparılması anlamına geleceği, Türkiye ve dünyadaki akademik köklerinden uzaklaştırılacağı (Doğan, 2012:22) değerlendirmesinin, Türkiye'de sosyolojinin tarihsel gelişiminde eğitimle ilişkisinde mesafeli olduğu, gündeminde yer vermediği düşünüldügünde bir karşılığı olmayacaktır. Dolayısıyla uygulamalı bir disiplinlerarası disiplin olan eğitim sosyolojisinin, Türkiye'deki tarihsel sürekliliğinin sosyoloji içerisinde gerçekleş/e/mediği söylenebilir.

1917'den 2020 y1lına kadar kesintili 103 yıl, kesintisiz 58 yıl yayınlanan Sosyoloji dergilerinde (İçtimaiyat Mecmuası ve İ.Ü Sosyoloji dergisi), derginin web sayfasına bakıldığında, eğitim sosyolojisine ilişkin makale ve yazı sayısının, yaklaşık 13 yıl yayınlanan Darülfünun Edebiyat Fakültesi Mecmuasındaki makale sayısı (12 makale) kadar olmadığ görülmektedir. İngiltere'deki üç ana sosyoloji dergisinin (Sociological Review, British Journal of Sociology ve Sociology) 19102000 yıllarındaki yayınlarında eğitimle ilgili makale oranı \% 10'dur ve dokuz konu alanına göre yayınlar sıralandığında eğitim genel toplamda 7. Sırada yer almaktadır. ${ }^{21}$ Bununla paralel biçimde başka bir çalışmada, 1998-2003 yıllarında bu dergilerde yayınlanan makalelerin yaklaşı \% 4'ünün

${ }^{21}$ Bk. A. H. Halsey, A History of Sociology in Britain, Oxford University Press, 2004,s. 185 
eğitim üzerine olduğu görülmektedir. ${ }^{22}$ Benzer bir çalışmada ${ }^{23}$ 1981-1990 döneminde Almanya, Amerika ve İngiltere'deki dört sosyoloji dergisinde (Kölner Zeitschrift für Soziologie and Soszialpsychologie, American Journal of Sociology, American Sociological Review ve The British Journal of Sociology) yayınlanan 200 sayının 1712 makalesinde eğitim sosyolojisine ilişkin makale ortalaması \% 3,5'dur. Dolayısıyla gerek içtimaiyat mecmuasında gerek devamındaki sosyoloji dergisinde eğitim bir çalışma alanı olarak kendisine yer bulamamış, eğitimle ilgili çalışmalar oldukça sınırlı sayıda kalmıştır. Bu durum Batı ülkelerinde yayınlanan makalelerde de görülmektedir. Bu çerçevede sosyolojinin kurumsallaşmasında önemli yeri olan bu iki dergide dahi, günümüz sosyologları tarafından alt disiplini olarak kabul edilen eğitim sosyolojisine ilişkin çalışmaların sinırlılı̆̆ 1 , bu disiplinin Türkiye'deki seyrinde sosyolojinin gündeminde olmadığının göstergelerindendir. Bu yönüyle Türkiye'de sosyolojinin krizde olduğu değerlendirmelerinde, eğitim sosyolojisinin de krizi olmasından ${ }^{24}$ söz edilemeyeceği gibi, bu krizin başından beri bir meşruiyet krizi olduğu söylenebilir. Diğer bir ifadeyle bu bakış açısıyla üst bilim alanının, sosyolojinin krizi, alt bilim alanlarının da krizi olarak değerlendirilmektedir. Oysaki Türkiye'de eğitim sosyolojisinin, sosyolojinin alt disiplini olduğu değerlendirmelerinde, sosyolojinin Türkiye'deki serüveninde karşılığını bulamadığı görülmektedir.

Eğitim sosyolojisine, Türkiye'de Üniversitelerarası Kurul'un doçentlik bilim alanlarından hem eğitim bilimlerinin hem de sosyolojinin alt alanı olarak yer verilmesi, alanyazın tartışmalarında sıklıkla yer verilmeyen, ikili kabulün, sosyolojinin ve eğitim bilimlerinin bir alt disiplini olduğu kabulünün sonucudur. Elbette bu kabül ile birlikte Türk sosyologlarının toplumun bütününden ziyade onun içindeki bir alt sistemi, bir ağ 1 , bir kategoriyi, bir eğilimi incelemeyi tercih etmeleri, giderek daha çok mikro ve mezo boyutlara yönelmeleri (Çelebi, 2010:61) de bir etken olabilir. Bunun yanı sıra uygulamalı ve disiplinlerarası bir bilim alanı olan eğitim bilimlerinin ve alt disiplinlerinin, kuramsal çalışmaların yoğun olarak yapıldığı bilim alanlarıyla etkileşiminin sınırlı olacağı söylenebilir. Bu çerçevede Türkiye'de eğitim sosyolojisi disiplininin, her ne kadar sosyolojinin bir alt disiplini olduğu kabulü sosyologlar arasında oldukça yaygın olsa da, aslında tamamıyla varlık alanı, ortaya çıkması ve gelişmesi eğitim bilimlerinin içerisindedir. Dolayısıyla uygulamalı ve disiplinler arası bir çalışma alanı olarak eğitim sosyolojisinin, eğitim bilimlerinin içerisinde akademik gelişimini sürdürmesi tarihsel sonucudur. Ancak eğitim sosyolojisi çalışmalarının disiplinlerarası bir bakışla ele alınmasının kaçınılmazlığı, bu konuda yapılmış çalışmaların sınırlılığı, bu alanda çalışan araştırmacıların da sosyolojinin cazibesinden kendilerini kurtaramayarak eğitim sosyolojisi disiplininin sosyoloji bilimine hizalanmasına katkıda bulunmaları eğitim sosyolojisinin, sosyoloji biliminin hegemonyasında kalmasına neden olduğu söylenebilir.

1965 tarihli yönetmelikle Ankara Üniversitesi Eğitim (Bilimleri) Fakültesi’nin kuruluş yapısı içinde yer alarak bağımsız bir birim haline gelen eğitim sosyolojisi kürsüsü, 1974 yılında Eğitimin Sosyal ve Tarihi Temelleri (ESTT) Bölümü olarak yeniden yapılandırılmıştır. Eğitim sosyolojisi, 1982 yılından 1997 yılına kadar Eğitim Programları ve Öğretimi Bölümü’nde Eğitimin Sosyal ve Tarihi Temelleri olarak bir ana bilim alına, 1997 yılından 2007 yılına kadar Eğitim Bilimleri Bölümü içerisinde ESTT adıyla bir bilim dalına indirgenmiştir. 2007 yılından 2016 yılına kadar Eğitimin Kültürel Temelleri Bölümü'nde ESTT ana bilim dalı olarak, bu tarihten itibaren ise Eğitim Bilimleri Bölümü içerisinde Eğitimin Felsefi, Sosyal ve Tarihi Temelleri Ana Bilim Dalı olarak akademik yapılanmada gelişimini sürdürmektedir. Bunun yanı sıra eğitim sosyolojisinin Ankara Üniversitesi'nde 1967 yılında başlayan lisansüstü programlardaki eğitimi, 1998 yılında Gazi

\footnotetext{
${ }^{22}$ Bk. Rosemary Deem, Sociology and the sociology of higher education: A missed call or a disconnection?, International Studies in Sociology of Education, 2004, s.26.

${ }^{23}$ Bk. Sabahattin Güllülü, Mustafa Gündüz ve Eyüp Kemerlioğlu, Alman, Amerikan ve İngiliz Sosyolojisinin Son On Yıl1, Dünya'da ve Türkiye'de Güncel Sosyolojik Gelişmeler, I. Ulusal Sosyoloji Kongresi, 3-5 Kasım 1993, İzmir, Sosyoloji Derneği Yayınları, s.58-70.

${ }^{24}$ Bk. Ali Esgin, The Crisis of the Sociology of Education and Its Reflections in Turkey: On the Critique of Functionalist and Eclecticist Pragmatic Tradition, Egitim Arastirmalari-Eurasian Journal of Educational Research, 2013, s. 143-162.
} 
Üniversitesi, 2009 yılında Samsun On Dokuz Mayıs Üniversitesi'nin de eklenmesiyle, 2020 y1lında Eğitim Bilimleri Enstitülerinde Eğitimin Felsefi, Sosyal ve Tarihi Temelleri adıyla devam etmektedir.

1965 yılında bağımsız bir birim olan eğitim sosyolojisi kürsüsü, eğitim bilimleri ve öğretmen yetiştiren fakülte programlarında, öğretmen olmak için ihtiyaç duyulan pedagojik formasyon sertifika programlarında eğitim sosyolojisi dersi ile zorunlu dersler arasında yer almış ve kendisine bağlı çeşitli dersleriyle de varlık alanını genişletmiştir. Bunun yanı sıra eğitim sosyolojisi dersi, 2547 sayılı Yükseköğretim Kanunu öncesinde öğretmen yetiştiren İlköğretmen okulları ve Eğitim Enstitülerinde zorunlu dersler, Yükseköğretmen okullarında ise seçmeli dersler arasında yer almıștır (Ankara Üniversitesi, 1967:22-26). Dolayısıyla 1965 y1lından itibaren eğitim sosyolojisi disiplininin kendi meşruiyet zeminini ve akademik gelişimini yoğun olarak eğitim bilimleri içerisinde sürdürdüğü görülmektedir. Diğer bir ifadeyle Türkiye'de eğitim sosyolojisi disiplininin, ontolojik ve epistemolojik ardalanının eğitimbilimleri içerisinde oluştuğu ve geliştiği söylenebilir.

ESTT bünyesindeki temel derslerin, 1997 yılından 2016 yılına kadar geçen yaklaşık 20 yıllık sürede Eğitim Fakültelerinin ve Eğitim Bilimleri Fakültesi'nin lisans programlarında yer almaması ESTT’nin gelişimini sekteye uğratmıştır. Aslında bu düzenlemenin eğitim bilimlerinin tamamının gelişimini frenleyen bir özelliği bulunmaktadır. ESTT kapsamına giren derslerin kaldırılması, Türkiye'de bu alanın eğitimdeki rolünün ve öneminin azaltılmasına, bir başka program içerisine sıkıştııılmasına, çalışma alanının daraltılmasına yol açsa da, ESTT çalışma alanına giren konuların, aslında eğitim bilimlerinin diğer disiplinlerinin çalışma konuları içerisinde kendisine oldukça fazla biçimde yer bulabilmesine yol açtı̆̆ söylenebilir. Kuşkusuz bunda eğitim bilimlerinin interdisipliner bir bakış açısına sahip olmasının da etkisi yadsınamaz. Buna karşın Türkiye'de eğitim sosyolojisi disiplinin, sosyolojinin bir alt disiplini olduğu değerlendirmesi, sosyoloji ve eğitim sosyolojisi kitaplarında vurgulanan bir ifade olsa da sosyologların, kendi içlerindeki atomistik/holistik bakış açılarının uzlaşmazlığının yanı sıra eğitim dışında diğer toplumsal kurumlara ve sorunlara öncelik vermeleri, çalışmalarında kendinden önceki çalışmalardan etkilenme ve kendilerini benzeştirmeleriyle konu alanlarının da yeniden üretimine neden olmalarının sonucunda eğitim sosyolojisi, sosyoloji bilimi içerisinde varolamamış ve gelişememiştir. Bunun yanı sıra, Türkiye'de üniversitelerde ders kitabı olarak okutulan başta eğitim sosyolojisi kitabı olmak üzere diğer bilim alanlarının / disiplinlerinin çoğunluğunun kitaplarında da rahatlıkla görülebileceği gibi, kitap içeriklerinin, kendinden önceki çalışmalardan etkilenme ve kendilerini benzeştirmeleriyle yeniden üretilerek adeta bir "papağan öğrenmesi" biçiminin hakim olduğu ve böylelikle "ilk sözü söyleyenin" işlevsel olarak takip edildiği bir alanyazının ortaya çıktığı söylenebilir. Elbette YÖK'ün öğretmen yetiştiren programlardaki dersler için kur tanımında bulunması, bu sürecin benzeşmesinde bir etken olarak değerlendirilebilse de, bu tanımlamanın derslerin konularına ilişkin bir çerçeve metni olduğu ve konu içerikleri yönüyle belirleyiciliğinin olmadığı söylenebilir. Bunun yanı sıra üniversitelerdeki araştırmaların, yayınların ve projelerin her dönemin popüler konularıyla yakın ilişkisi, diğer bir ifadeyle toplumsal koşulların dönüşümüyle birlikte ortaya konulan çalışmaların popülerlik, moda, gündemde olan konular etrafında yoğunlaşması, konu alanlarının / içeriklerinin de yeniden üretimine yol açtı̆̆ 1 söylenebilir.

Sonuç olarak, Türkiye'de eğitim sosyolojisinin, sosyolojinin başlangıcından günümüze varoluş sürecinde kendi mecraını, bu alanda çalışan sınırlı sayıdaki eğitim bilimcilerin de sosyoloji içerisinde ele almalarının da sonucu olarak sosyolojiye hizalanmaya çalışılsa da tarihsel akış, bu disiplinin yönünün eğitim bilimlerinde olduğunu göstermektedir. Elbette bu durum, sosyolojinin yöntem, teknik ve verilerinin eğitim sosyolojisinde kullanılamayacağı, sosyolojinin verilerini kullanmaksızın eğitim sosyolojisinin varolabileceği anlamına gelmese de, eğitim sosyolojisinin sadece sosyolojiden hareket etmediği, ancak Türkiye'deki seyrinde eğitim bilimleri içerisinde kurumsallaştığı anlamını taşımaktadır. Türkiye'de eğitim sosyolojisi mazide filizlenmiş, kökü, 
gövdesi, dalı, budağıyla atiye sarmalanmış, farklı bilim alanları / disiplinleriyle birlikte eğitimbilimlerinin içerisinde, disiplinlerarası bir disiplin olarak varlığını sürdürmektedir.

\section{Kaynakça}

Akyüz, H. (1992). Eğitim sosyolojisinin temel kavram ve alanları üzerine bir araştırma. Milli Eğitim Bakanlığı Yayınları.

Altunya, N. (2018). Türkiye'de eğitim bilimleri öğretimi: başlangıçtan 1965'e kadar. PegemAkademi Yayıncılık.

Ankara Üniversitesi Eğitim Fakültesi Lisans Öğretim ve İmtihan Yönetmeliği. (1965). Resmi Gazete, Say1:12082.

Ankara Üniversitesi (1967). Çeşitli memleketlerde üniversitelere bağlı eğitim fakülteleri ĕgitim enstitüleri, eğitim kolejleri, eğitim bölümleri ve kürsüleri. Ankara Üniversitesi Eğitim Fakültesi Kuruluş Yayınları No:2. Ankara Üniversitesi Basımevi.

Ankara Dil, Tarih, Coğrafya Fakültesi Esas Talimatnamesi. (1939). Maarif Vekilliği Kültür Kurulu Kararı. Sayı: 40,41.

Ankara Dil ve Tarih-Coğrafya Fakültesi 1941-1942 ders yılı talebe rehberi (1942). İdeal Matbaası.

Aslan, C. (2014). Erken Cumhuriyet döneminde eğitim bilimleri alanında yurtdışına öğrenci gönderilmesi olgusu [Yayımlanmamış doktora tezi]. Ankara Üniversitesi Eğitim Bilimleri Enstitüsü.

Aslan, C. (2019). Türkiye'de ĕgitim bilimlerinin kurumsal gelişimi. Prof. Dr. Mehmet Ali Klsakürek'e armă̆an. Ankara Üniversitesi Basımevi.

Aytaç, K. (2010). Hayatım ve mesleğim.

[Baltacıoğlu] Ismayıl Hakkı (1340). Ictimâ 'iyyât nokta-i nazarından terbiye. Matbaa-1 Amire.

Baltacıoğlu, I. H. (1998). Hayatım. (Yay. Haz. A. Y. Baltacıŏlu), Dünya Yayınları.

Bilhan, S. (1996). Eğitim sosyolojisi. Ankara: Ankara Üniversitesi Eğitim Bilimleri Fakültesi Yayınları.

Cangızbay, K. (1999). Sosyolojiler değil sosyoloji. Ütopya Yayınları.

Çadırcı, M. \& Süslü, A. (1982). Ankara Üniversitesi gelişim tarihi. Atatürk'ün 100. doğum yllına armağan. Ankara Üniversitesi Rektörlüğü Yayınlan, No:82. Ankara Üniversitesi Basımevi.

Çelebi, N. (2010). Türkiye'de Sosyoloji. (Ed.) E. Eğribel ve U. Özcan. Türk Sosyologları ve Eserleri II, Genel Eğilimler ve Kurumsallaşma. Kitabevi.

Deem, R. (2004). Sociology and the sociology of higher education: A missed call or a disconnection?. International Studies in Sociology of Education, 14 (1), 21-46.

Doğan, İ. (2018). Eğitim sosyolojisi kavramlar ve sorunlar. Nobel Yayınc1lık.

Doğan, İ. (2012). Eğitim sosyolojisinin Türkiye'deki serüveni. Eğitim sosyolojisi: dün, bugün, yarın. Nobel Yayınları.

Dölen, E. (2009). Türkiye Üniversite tarihi I Osmanl döneminde Darülfünun 1863-1922. Bilgi Üniversitesi Yayınları.

Dölen, E. (2008). II. Meşrutiyet döneminde Darülfünun. Osmanlı Bilimi Araştırmaları, X (1), 1-23. 
Durkheim, E. (1917). İlm-i Terbiye ve İçtimaiyat. İstanbul Üniversitesi Sosyoloji Dergisi, 1 (5), 207 224.

Ercan, R. (2013). Türkiye'de Sosyolojinin Gelişimi ve Ĕgilimleri İstanbul Üniversitesi Sosyoloji Dergisi. Anı Yayınc1l1k.

Ergün, M. (1994). Eğitim sosyolojisine giriş. Ocak Yayınları.

Erişçi, L. (1941). Türkiye'de sosyolojinin tarihçesi ve bibliyografyası. İstanbul Üniversitesi Sosyoloji Dergisi, 2 (1), 159-169.

Esgin, A. (2013). The Crisis of the sociology of education and its reflections in Turkey: On the critique of functionalist and eclecticist pragmatic tradition. Egitim Arastirmalari-Eurasian Journal of Educational Research, 50, 143-162.

Fındıkoğlu, Z. (1947). İçtimaiyat. İstanbul Üniversitesi Hukuk Fakültesi Yayınları, No: 70. İsmail Akgün Matbaasi.

Fraenkel, Jack R., Wallen, Norman E. ve Hyun, Helen H. (2012). How to design and evaluate research in education. McGraw-Hill Higher Education.

Gencer, A. İ \& Arslan, A. (2004). İstanbul Dârülfünûnu Edebiyat Fakültesi tarihçesi ve ilk meclis zabitları. İstanbul Üniversitesi Edebiyat Fakültesi Yayınları.

Gökçe, B. (1994). Açılış konuşmaları. Dünya'da ve Türkiye'de güncel sosyolojik gelişmeler. I. Ulusal Sosyoloji Kongresi (3-5 Kasım, İzmir). Sosyoloji Derneği Yayınları.

Güllülü, S., Gündüz, M. \& Kemerlioğlu, E. (1993). Alman, Amerikan ve İngiliz sosyolojisinin son on y1l1, Dünya'da ve Türkiye'de güncel sosyolojik gelişmeler, I. Ulusal Sosyoloji Kongresi (3-5 Kasım, İzmir). Sosyoloji Derneği Yayınları.

Halsey, A. H. (2004). A History of sociology in Britain, Oxford University Press.

Hirsch, E. E. (1998). Dünya üniversiteleri ve Türkiye'de üniversitelerin gelişimi. C. 1.: Ankara Üniversitesi Yayınları.

İlyasoğlu, A. (2001). Türkiye'de sosyolojinin tarihini yazmak: bir sorunlaştırma ve yaklaşım önerisi. sosyal bilimleri yeniden düşünmek, Sempozyum Bildirileri. Metis Yayıncılık.

İnal, K. (2014). Toplum ve eğitim ilişkilerinin bilimi. (Ed.) Ç. Özdemir, Eğitim sosyolojisi. Pegem Akademi Yayınc1lık.

İstanbul Darülfünunu Talebe Rehberi: 1339-1340 (1339). Matbaa-1 Amire

İstanbul Darülfünunu Talebe Rehberi: 1930-1931 (1930). Ekspres Matbaas1.

İstanbul Üniversitesi Edebiyat Fakültesi 1936-1937 ders yılı Talebe K1lavuzu (1936). Resimli Ay Basımevi.

İstanbul Üniversitesi (1955). İktisat Fakültesi, İçtimaiyat Enstitüsü hakkında kuruluşunun XX. yılı münasebetiyle rapor (1934-1954). İstanbul: İstanbul Üniversitesi Yayınları.

İstanbul Üniversitesi Edebiyat Fakültesi 1937-1938 ders y1lı Talebe Kılavuzu (1937). Burhanettin Matbaas1.

İstanbul Üniversitesi İktisat Fakültesi Sosyoloji Enstitüsü Hakkında Yönetmelik (1976). Resmi Gazete, Sayı: 15567.

İstanbul Üniversitesi Edebiyat Fakültesi Öğretim ve Sınav Yönetmeliği (1983). Resmi Gazete, Say1:17969. 
Kaçmazoğlu, B. (2010). İstanbul Üniversitesi İktisat Fakültesi sosyologları: sosyal siyasetçi, milliyetçi ve bütüncü sosyoloji ekolü. (Ed.) E. Eğribel ve U. Özcan, Türk Sosyologları ve Eserleri II, Genel Eğilimler ve Kurumsallaşma. Kitabevi.

Kaçmazoğlu, B. (1994). 1960 Sonrasında Türkiye'de yapılan sosyoloji çalışmalarına genel bir bakış. Dünya'da ve Türkiye'de güncel sosyolojik gelișmeler. I. Ulusal Sosyoloji Kongresi (3-5 Kasım, İzmir). Sosyoloji Derneği Yayınları.

Kafadar, O. (1998). Türkiye'de yükseköğretimde felsefe eğitimi -tarihsel gelişim ve lisans eğitiminin bir incelemesi [Yayımlanmamış doktora tezi]. Ankara Üniversitesi Sosyal Bilimler Enstitüsü.

Kanad, H. F. (1958). Terbiye sosyolojisi, Yeni Matbaa.

Kazancıgil, A. \& Vergili, A. (2002). İstanbul Darülfünunu Edebiyat Fakültesi Mecmuası (inceleme ve dizin). Türklük Bilimi Araştırmaları, 12, 27-74.

Kongar, E. (1993). Türk toplumbilimcileri. Remzi Kitabevi.

Köymen, N. (1953). Eğitim sosyolojisi. Milli Eğitim Basımevi.

Lauder, H., Brown, P \& Halsey, A. H. (2011). The sociology of education as 'redemption': a critical history. Ed. J. Furlong \& M. Lawn, Disciplines of education, their role in the future of education research. Routledge.

Maarif Vekâleti (1953). Beşinci Milli Eğitim Şûrası. Maarif Vekâleti Yayınları.

Malche, A. (1939). İstanbul Üniversitesi hakkında rapor. Devlet Basımevi.

Mehmet Ali Ayni (1927). Darülfünun tarihi. Yeni Matbaa.

Miser, R. (2016). Türk pedagoji çınarı 50 yaşında: Ankara Üniversitesi Eğitim Bilimleri Fakültesi (1965-2015). Ankara Üniversitesi Eğitim Bilimleri Fakültesi Yayınları.

Morrish, I. (1972). The Sociology of education an introduction. Routledge.

Necmettin Sadak (1917). İçtimaiyat nedir?. İstanbul Üniversitesi Sosyoloji Dergisi, 1 (1), 15-21.

Özcan, U. (2010). Türkiye'de sosyoloji: başlıca akımlar, dönemler ve figürler. (Ed.) E. Eğribel ve U. Özcan. Türk Sosyologları ve Eserleri II, Genel Eğilimler ve Kurumsallaşma. Kitabevi.

Sözer, M. A. \& Sever, M. (2012). Amerika Birleşik Devletleri'nde eğitim sosyolojisi. Eğitim sosyolojisi: dün, bugün, yarın. Nobel Yayınc1l1k.

Stalcup, R. J. (1968). Sociology and education. Charles E. Merrill Publishing Company.

Swift, D. F. (2017). The Sociology of education introductory analytical perspectives. Routledge.

Şemin, R.U. (1973). Eğitim bilimlerinin üniversiteye girişi: Pedagoji Enstitüsü’nün kuruluşu ve gelişimi. İstanbul Üniversitesi Edebiyat Fakültesi Cumhuriyetin 50. yılına armağan.

Tan, M. (1981). Toplumbilimine giriş: temel kavramlar. Ankara Üniversitesi Eğitim Fakültesi Yayınları.

Tanyu, H. (1981). Ziya Gökalp kronolojisi. Kültür Bakanlı̆̆1 Yayınları.

Tezcan, M. (1985). Eğitim sosyolojisi. Ankara Üniversitesi Eğitim Bilimleri Fakültesi Yayınları.

Tolan, B. (2005). Sosyoloji. Gazi Kitabevi.

Tonguç, İ. H. (1952). Öğretmen ansiklopedisi ve pedagoji sözlü̆̆̈̈. Bir Yayınevi. 
Topçuoğlu, H. (1971). Eğitim sosyolojisi (kaynak metinler). Ankara Üniversitesi Eğitim Fakültesi Yayınları.

Türkdoğan, O. (1996). Çağdaş Türk sosyolojisi. Turan Yayınc1lık.

Ülken, H. Z. (2008). Dünyada ve Türkiye'de sosyoloji öğretim ve araştırmaları. Kitabevi.

Ülken, H. Z. (1954). Milli Eğitim Bakanlığı yüksek makamına. İstanbul Üniversitesi Sosyoloji Dergisi, 2 (9), 59-66.

Ülken, H. Z. (1941). Sosyolojinin mevzuu ve usulü. İstanbul Üniversitesi Sosyoloji Dergisi, 2 (1), 3142.

Yalvaç, M. (2010). İstanbul Üniversitesi Edebiyat Fakültesi'nde sosyoloji eğitiminin tarihçesi (19121982). (Ed.) E. Eğribel ve U. Özcan. Türk sosyologlart ve eserleri II, genel eğilimler ve kurumsallaşma. Kitabevi.

Zaim, S. (2007). İ.Ü. İktisat Fakültesi çalışma ekonomisi ve endüstri ilişkileri bölümünün tarihçesi ve gelişimi. Sosyal Siyaset Konferansları Dergisi, 52, 321-336. 